\title{
Hydrothermal sediments record changes in deep water oxygen content in the SE Pacific
}

Rachel A. Mills, Sarah L. Taylor, Heiko Pälike and John Thomson

National Oceanography Centre, University of Southampton, European Way, Southampton, SO14 3ZH, UK

\begin{abstract}
The distribution of redox-sensitive metals in sediments is potentially a proxy for past ocean ventilation and productivity, but deconvolving these two major controls has proved difficult to date. Here we present a $740 \mathrm{kyr}$ long record of trace element concentrations from an archived sediment core collected at $\sim 15^{\circ} \mathrm{S}$ on the western flank of the East Pacific Rise on 1.1 Ma old crust, and underlying the largest known hydrothermal plume in the world ocean. The downcore trace element distribution is controlled by a variable diagenetic overprint on the inferred primary hydrothermal plume input. Two main diagenetic processses are operating at this site: redox cycling of transition metals and ferrihydrite to goethite transition during aging. The depth of oxidation in these sediments is controlled by fluctuations in the relative balance of bottom water oxygen and electron donor input (organic matter and hydrothermal sulfides). These fluctuations induce apparent variations in the accumulation of redox-sensitive species with time. Sub-surface $\mathrm{U}$ and P peaks in glacial age sediments, in this and other published data sets along the Southern EPR, indicate that basin-wide changes in deep ocean ventilation, in particular at
\end{abstract}


glacial-interglacial terminations II, III, IV and V, alter the depth of the oxidation front in the sediments. These basin-wide changes in the deep Pacific have significant implications for carbon partitioning in the ocean-atmosphere system and the distribution of redox-sensitive metals in ridge crest sediment can be used to reconstruct past ocean conditions at abyssal depths in the absence of alternative proxy records.

Index terms: Paleoceanography $(0473,3344)$, geochemical tracers (4924), glacial (4926), interglacial (4936)

\section{Introduction}

Hydrothermal sediments derived from plume dispersion of vent derived particles accumulate around tectonically-active margins such as mid-ocean ridges [Mills and Elderfield, 1995], but are rarely exploited for paleoceanographic reconstruction of past ocean conditions because of the complexity of inputs and post-depositional changes in these sediments. Iron-oxide hydrothermal particles co-precipitate certain trace elements (e.g. U, Mo, As, P, V) from seawater [Edmonds and German, 2004; Feely et al., 1996] and many trace metals (e.g. $\mathrm{Fe}, \mathrm{Cu}, \mathrm{Zn}, \mathrm{U}, \mathrm{Mo}, \mathrm{Cd}, \mathrm{Pb}$ ) are enriched in sulfide particles which are transported along with the Fe oxides [Trocine and Trefry, 1988]. The sedimentary record of these elements depends on the nature and extent of postdepositional reactions at the seafloor [Poulton and Canfield, 2006]. The trace element record in metalliferous sediments can potentially reveal past changes in ocean chemistry if the seawater record is preserved [Edmonds and German, 2004; Feely et al., 1996], but problems in interpretation arise because the record can be perturbed during suboxic 
diagenesis [Schaller et al., 2000] and low-temperature fluid flow [Mills and Dunk, 2010]. Furthermore, in sediments with low accumulation rates, bioturbation and sediment redistribution smooth the record of past changes.

In the abyssal South Pacific the sediment records are significantly impacted by hydrothermal inputs, and generating a record of past change in this setting has remained a challenge. The Southern East Pacific Rise (SEPR) between 13 and $18^{\circ} \mathrm{S}$ is a site of intense hydrothermal activity [Lupton and Craig, 1981], and particle-rich plumes are present along more than half of the ridge axis in this region [Feely et al., 1996]. The metalliferous sediment distribution in this region of the SE Pacific is controlled by westward flow at $\sim 2500 \mathrm{~m}$ depth [Reid, 1982] which transports the hydrothermal plume over hundreds of $\mathrm{km}$ [Dymond, 1981]. Systematic downcore variation in oxyanion [Poulton and Canfield, 2006] and trace metal [Schaller et al., 2000] content has been observed in young crustal and ridge flank sediments from this sector. In particular, subsurface uranium concentration peaks are common along the EPR from $10^{\circ} \mathrm{S}[$ Schaller et al., 2000] to $20^{\circ} \mathrm{S}$ [Shimmield and Price, 1988] (Fig. 1). The origin and implications of these subsurface uranium enrichments in EPR sediments have been debated over several decades but not satisfactorily explained. Subsurface enrichments have previously been attributed to diffusive uranium uptake from seawater and fixation in suboxic sediments under higher productivity glacial conditions [Yang et al., 1995], scavenging of seawater uranium by variable inputs of reactive hydrothermal plume particles [Shimmield and Price, 1988] and within-sediment transport [Mills and Dunk, 2010] and precipitation from uranium-rich fluids [Rydell et al., 1974; Schaller et al., 2000]. Deciphering the 
origin of these uranium peaks would provide new information for an ocean region with sparse Pleistocene proxy records.

Volumetrically the deep Pacific Ocean makes up a significant proportion of the global ocean and thus changes in Pacific circulation, ventilation and deep water nutrient, and carbon content can have a major impact on biogeochemical cycles. Most late Pleistocene reconstructions of the Pacific have focussed on productivity variations [e.g. Martinez and Robinson, 2009] and changes to ventilation of the upper water column [e.g. Stott et al., 2009]. Recent combined proxy and modelling approaches suggest reorganisation of the North Pacific deep water ventilation during the last glacial termination may have had a significant impact on global heat transfer [Okazaki et al., 2010] but there are limited proxy records to test this hypothesis, particularly in the south Pacific.

Paleoceanographic records from the SE Pacific are sparse because carbonate sedimentation is restricted to the hydrothermally-dominated ridge region. The published sedimentary records along the EPR lack age models and often the depth sampling resolution is inadequate. Our knowledge and understanding of past change would be significantly enhanced if the hydrothermal plume input and post-depositional changes within the sediment record could be deciphered and interpreted to reconstruct paleoceanographic and paleoclimatic conditions for this ocean.

Here we present new age controlled data for an archived sediment core originally studied by Rydell et al. [1974] that demonstrates that diagenetic overprinting of hydrothermal inputs from the SEPR records significant glacial-interglacial changes in ventilation of the deep ocean moderated by intense redox cycling at glacial terminations II, III, IV and V 
during the Pleistocene. Comparison with published records along the SEPR suggests that these changes were basin wide and may thus significantly impact the storage of respired carbon in the deep ocean and poleward oceanic heat transport.

\subsection{Paleoceanographic Setting}

The EPR ridge-crest from 10 to $20^{\circ} \mathrm{S}$ underlies low-productivity oligotrophic subtropical waters and is bathed by North Pacific Deep Water (NPDW: $\mathrm{T}<2^{\circ} \mathrm{C}, \mathrm{O}_{2}<150 \mu \mathrm{M}$ [Fiedler and Talley, 2006]) which recirculates southwards from the North Pacific as the major return flow of the overturning circulation in this basin. This water mass underlies the well-ventilated intermediate modal waters sourced from the Southern Ocean [Fiedler and Talley, 2006]. The nutrient maximum and oxygen minimum associated with the modern NPDW outflow is centred at $\sim 2000 \mathrm{~m}$ depth in the modern ocean. This return flow is hypothesized to have deepened to $2500-3000 \mathrm{~m}$ depth during the Last Glacial Maximum [Sigman and Boyle, 2000; Matsumoto et al., 2002] sequestering nutrients and respired carbon to the abyss and thus lowering atmospheric $\mathrm{pCO}_{2}$ [Boyle, 1988]. This hypothesis has been tested extensively by attempts to reconstruct glacial Pacific nutrient

distributions but has been hampered by apparently contradictory proxy records (e.g., $\delta^{13} \mathrm{C}$ [Matsumoto et al., 2002] and $\mathrm{Cd} / \mathrm{Ca}$ [Boyle, 1992]). Redox-sensitive metal records have been used in various ocean basins to identify glacial decrease in abyssal water oxygen content [e.g., Galbraith, 2007]. These different proxy records have recently been reconciled by the identification of an enhanced glacial respired carbon pool in the deep NW Pacific with lower oxygen levels but unchanged phosphate content arising from shifts in preformed nutrient supply [Jaccard et al., 2009]. 
Glacial terminations are the times when the strongest changes in deep water ventilation and thereby oxygen levels, sedimentation rates, and input of electron donors occurs [Broecker and Denton, 1989]. Glacial terminations with global evidence for reconfiguration of ocean circulation occur at the ends of Marine Isotope Stage (MIS) 12 (V), 10 (IV), 8 (III), 6 (II) and 2 (I). There is evidence from the Pacific for basin-wide maxima in export production during early deglaciation which in turn impacts on bottom water oxygen content [Martinez and Robinson, 2010]. The inferred deglacial shifts in deep Pacific ventilation will also have significant controls on abyssal water oxygen levels [Okazaki et al., 2010].

At glacial terminations where benthic redox processes are perturbed, nonsteady-state diagenetic processes are initiated which lead to post-depositional diagenetic overprint within these sediment intervals [Thomson et al., 1996]. Sedimentary redox driven diagenesis occurs throughout the redox gradient surrounding the oxidation front [Thomson et al., 1996]. Here we use the term oxidation front in a general way to describe the region just above and just below the limit of oxygen penetration, where a range of elements undergo redox cycling at different levels within the sediment in response to rapidly changing redox conditions. Solid phase Mn(IV) accumulates above the oxidation front in oxic conditions, supplied by reduced $\mathrm{Mn}(\mathrm{II})(\mathrm{aq})$ from below. Conversely solid phase, authigenic $\mathrm{U}(\mathrm{IV})$ accumulates under post-oxic conditions within the oxidation front, supplied by dissolved U(VI) from above. Several other redox-sensitive elements are mobile and reactive within the oxidation front and can form local enrichment peaks between those of Mn and U [Thomson et al., 1996].

\section{Sampling and methods}


The core GS7202-35 was recovered from $82 \mathrm{~km}$ west of the EPR ridge axis at $14^{\circ} 47.9^{\prime} \mathrm{S}$, $113^{\circ} 30.1^{\prime} \mathrm{W}$ from a water depth of $3044 \mathrm{~m}$ and comprised trigger and piston cores $1.7 \mathrm{~m}$ and $8.47 \mathrm{~m}$ in length, respectively [Rydell et al., 1974]. The cores are archived in the Miami Core Repository at $4^{\circ} \mathrm{C}$ and were resampled in contiguous $5 \mathrm{~cm}$ strips $(\sim 4 \mathrm{kyr}$ increments) which were dried, ground and homogenised prior to geochemical analysis. Bulk carbonate $\delta^{18} \mathrm{O}$ and $\delta^{13} \mathrm{C}$ were measured on a Europa Scientific GEO 20-20 mass spectrometer and all data are expressed relative to the VPDP standard. Carbonate and organic carbon content were determined by difference using coulometry and by Carlo Erba $\mathrm{CHN}$ analysis. Major (Fe, Mn, Ca, Al, Si, Ti, P, K, Na) and trace element analyses (U, Mo, Cd, V, Cu, Ba, Br, I, S, Cl) were carried out using a Philips PW1400 fully automatic wavelength dispersive XRF. A subset of 25 samples was subjected to a total digestion procedure (Dunk and Mills, 2006) for analysis by Inductively Coupled PlasmaAtomic Emission Spectrometry. Analysis was carried out on a Perkin Elmer Optima 4300DV Precision ICPAES. Accuracy of these ICPAES analyses was assessed by comparison with USGS standard MAG-1 and was better than 1\%. XRF pellets were calibrated using matrix-matched standards comprising mixtures of USGS standards MAG-1, JLs-1, GXR-1, NIM-L, BE-N, SDo1, NOD-P-1 and NOD-A-1. Accuracy of the XRF analysis was also assessed by comparison with the ICPAES data and for all elements presented (Table 1 ) is better than $3 \%$ of the certified value.

We avoid issues relating to variable carbonate dilution downcore by reporting elemental ratios; all ratios are expressed in mass units $(\mathrm{g} / \mathrm{g})$. A comparison of the bulk sedimentary trace element/Fe ratios with the SEPR plume [Feely et al., 1996] and oxic metalliferous sediments from east of the ridge axis at the same latitude [Dunk and Mills, 2006] (Figs. 
4d; 7a-d) allows assessment of the inputs and post-depositional changes occurring with time. All data are for bulk sediment analysis including dried pore water salt.

\section{Results and Discussion}

\subsection{Age model and sediment accumulation}

The trigger and piston cores were combined into one continuous record using a combination of the downcore bulk $\delta^{18} \mathrm{O}$ and trace element profiles. The best Pearson correlation for all records was achieved when the piston and trigger core were overlapped by $27.5-32.5 \mathrm{~cm}$; all piston core depths have therefore been adjusted by $+135.25 \mathrm{~cm}$ relative to the published stratigraphy which assumed erroneously that the piston core sampled the sediment water interface [Rydell et al., 1974]. An age model for the sediment accumulation was constructed by correlation of the bulk sediment $\delta^{18} \mathrm{O}$ record with the astronomically-tuned composite time series obtained from cores V19-30, ODP 677 and ODP840 [Shackleton et al., 1990] using the Analyseries software [Paillard et al., 1996]. We estimate the uncertainty of the correlation to be $<10 \mathrm{kyr}$, with a clear identification of all glacial and interglacial periods in the records (Fig. 2a).

The $9.8 \mathrm{~m}$ combined core contains a $740 \mathrm{kyr}$ record which spans Marine Isotope Stages (MIS) 1 to 20 [Shackleton et al., 1990] with linear sedimentation rates (LSR) of 0.95-1.64 $\mathrm{cm} \mathrm{ky}^{-1}$ (Fig. 2c). There is no systematic glacial-interglacial change in inferred LSR but there is a notable decrease in LSR at the end of MIS 7, when the core location was $\sim 68$ $\mathrm{km}$ from the ridge axis. The lower sedimentation rate in the upper core $\left(\sim 1 \mathrm{~cm} \mathrm{kyr}^{-1}\right)$ means that glacial-interglacial differences are not as clearly resolved as those deeper in the core. The observed sedimentation rates are consistent with estimates from ${ }^{230} \mathrm{Th}_{\mathrm{xs}}$ 
decay in the upper 3 mbsf [Rydell et al., 1974] and estimated mean accumulation from seismic profiling [Hauschild et al., 2003]. At $15^{\circ} \mathrm{S}$ the sediment appears to drape the seafloor uniformly with little indication of lateral sediment transport [Hauschild et al., 2003]. There is little basement topographic variation and therefore minimal basal fluid advection through the sediment on this ridge flank compared with the eastern flank at this latitude [Mills and Dunk, 2010]. Based on estimated spreading rates [Grevemeyer et al., 2002], core GS7202-35 was located $\sim 25 \mathrm{~km}$ west of the EPR axis at $740 \mathrm{ka}$ and has moved a further $57 \mathrm{~km}$ off axis since that time.

Pleistocene sedimentary records are characterised by the mid-Pleistocene transition (MPT) which is manifest in the Pacific by significant changes in the bulk carbon isotope composition (Fig. 2b; [Shackleton and Hall, 1995]) and marked shifts in the inferred deep water ventilation by the South Pacific upper circumpolar deep water (UCDW) at 870ka and 450ka [Venuti et al., 2007]. The early deposition at site GS7202-35 (740-400 kyr) occurred during the MPT. The major shift in bulk carbon isotope composition recorded in Equatorial Pacific sediment has been interpreted as evolutionary succession in the nanofossil assemblage [Shackleton and Hall, 1995]. The bulk $\delta^{13} \mathrm{C}$ record for this core exhibits the main features seen in the Equatorial Pacific Pleistocene record, providing additional stratigraphic constraints for the proposed age model (Fig. 2b). There is evidence for a number of shorter-lived shifts in carbon isotope partitioning at this site at the ends of MIS 12, 10 and 8 (Teminations V, IV and III; Fig. 2b).

\subsection{Sediment composition}


The sediment of core GS7202-35 comprises a mixture of hydrothermal material derived from plume fallout (Fe sulfides and $\mathrm{Fe}$ and $\mathrm{Mn}$ oxyhydroxides) and biogenic carbonate $\left(\mathrm{CaCO}_{3}\right)$ with minor biogenic silica and aluminosilicates (Table 1; Fig. 3). The maximum lithogenic (basaltic) input at this site estimated from the bulk sediment $\mathrm{Al}$ content and the $\mathrm{Al}$ content of basalt at this latitude $(\mathrm{Al}=8.88 \%$ [Schramm et al., 2005]) is small $(0.52-1.57 \%$ of bulk sediment) and this component can be ignored in our discussion. Note that the highest basaltic inputs are observed towards the base of the core when the site was closer to the ridge axis. The biogenic carbonate content varies from $58-72 \%$ (Fig. $4 a$ ) with lower values in the deeper parts of the core that are diluted by the more intensive hydrothermal input (up to $40 \%$ ) when the core location was closer to the ridge axis. The main control on $\mathrm{CaCO}_{3}$ burial away from the equatorial productivity maximum is inferred to be carbonate preservation rather than changes in productivity [Murray et al., 2000; Anderson et al., 2008]. The characteristic changes in $\mathrm{CaCO}_{3}$ preservation are damped at the shallow ridge-crest and the dramatic glacial-interglacial fluctuations seen elsewhere in $\mathrm{CaCO}_{3}$ records in Pacific cores retrieved from greater water depths (>4200 m, [Murray et al., 2000]) are not observed in this shallower ridge flank $15^{\circ} \mathrm{S}$ record. However, the significant dissolution event associated with MIS 11 [Murray et al., 2000] is associated with a minima in $\mathrm{CaCO}_{3}$ content in this record (Fig 4a). The hydrothermal material preserved in the sediment largely consists of X-ray amorphous $\mathrm{Fe}$ and $\mathrm{Mn}$ oxides with a minor clay component $(<1 \%)$. Consideration of the sea salt elements $\mathrm{S}, \mathrm{Na}, \mathrm{Cl}, \mathrm{Br}$ indicate the presence of 100-2500 ppm excess $\mathrm{S}$ content relative to $\mathrm{Cl}$ throughout the core, and $\mathrm{Fe}$ sulfides have been observed by scanning electron microscopy of impregnated sections of sediment from the ridge crest at this 
latitude [Dunk and Mills, 2006]. So whilst sulfide oxidation will have occurred during 25 years of core storage, the presence of primary sulfides at this site is inferred from the excess S measured by XRF. The organic carbon content of the sediment is low throughout $(<0.2 \%)$ with no measurable variation with depth; these low values are consistent with published data from this oligotrophic region [Schaller et al., 2002].

Plume particles collected from the neutrally-buoyant plume overlying the super-fast spreading EPR consist of a mixture of Fe and Mn oxides and sulfide/elemental sulfur phases [Feely et al., 1996]. Plume particles collected from the neutrally-buoyant plume $\sim 25 \mathrm{~km}$ west of the ridge axis at $15^{\circ} \mathrm{S}$ contain significant particulate sulfur $(\sim 30 \mathrm{nmol} / \mathrm{L}$; particulate molar $\mathrm{S} / \mathrm{Fe} \sim 0.04)$ and particulate $\mathrm{Mn}(1-2 \mathrm{nmol} / \mathrm{L}$; particulate molar $\mathrm{Mn} / \mathrm{Fe}$ up to 0.1 [Feely et al., 1996]). Plume particles collected from further south on the EPR contain a particulate component characterised by high levels of reduced S, particulate $\mathrm{Mn}$ and methane [Feely et al., 1996]. Plume transported hydrothermal sulfides are inferred to contribute significant transition metals to sediments from $10^{\circ} \mathrm{S}$ and elsewhere on the EPR [Schaller et al., 2000; Poulton and Canfield, 2006]. Thus the two sources of electron donor to the sediment at this site are organic carbon export from overlying oligotrophic waters and hydrothermally-derived reduced sulfur species. The electron donor input to the sediment is inferred to be cyclical, either through glacial-interglacial variation in overlying productivity and carbon export or by variations in hydrothermal inputs from the EPR which in turn are moderated by bottom water oxygenation which is determined by abyssal ventilation rates.

\subsection{Fe and Mn diagenesis}


The core is highly enriched in Fe (4.2-12\%) and Mn (1.4-6.9\%) throughout (Table 1; Figs. 3 and 4b, c). The Fe content co-varies inversely with the $\mathrm{CaCO}_{3}$ content (Fig. 3) so that the dominant control on $\mathrm{Fe}$ content is the variable dilution with $\mathrm{CaCO}_{3}$ downcore. $\mathrm{Mn} / \mathrm{Fe}$ ratios are variable and high $(0.24-0.47$; Fig. $4 \mathrm{~d})$. These values are higher than oxic sediments east of the axis at this latitude (EXCO: $\mathrm{Mn} / \mathrm{Fe}=0.21-0.33$ [Dunk and Mills, 2006]) and elsewhere on the EPR $\left(10^{\circ} \mathrm{S}: 0.17-0.33\right.$ [Schaller et al., 2000], $20^{\circ} \mathrm{S}$ : 0.29-0.35 [Shimmield and Price, 1988]). These $\mathrm{Mn} / \mathrm{Fe}$ ratios are also higher than the inferred hydrothermal sediment endmember calculated for Nazca Plate metalliferous ridge-crest and flank sediments $(\mathrm{Mn} / \mathrm{Fe}=0.323 ;$ [Dymond, 1981]) throughout the core below $25 \mathrm{cmbsf}$, although $\mathrm{Mn} / \mathrm{Fe}$ values approach this modern sedimentary endmember value at glacial terminations V, IV, III and II (Fig. 4d). The source of additional Mn is inferred to be the hydrothermal plume inputs associated with super-fast spreading hydrothermalism as characterised by Mn- and S-rich particles collected on the SEPR [Feely et al., 1996].

Dissolved $\mathrm{Mn}(\mathrm{II})$ is the product of dissimilatory Mn reduction during early diagenesis and $\mathrm{Mn}$ (II) can also be derived from in situ reaction of Mn oxides with plume-derived sulfides [Aller and Rude, 1988; Schippers and Jørgensen, 2001]. The resultant $\mathrm{Mn}(\mathrm{II})$ is retained within the sediment both by sorption on carbonate surfaces and reprecipitation as diagenetic Mn(IV) phases in the oxic surface layer [Shimmield and Price, 1986; Thomson et al., 1986; Yang et al., 1995]. The relatively high $\mathrm{Mn} / \mathrm{Fe}$ ratios compared with ridgecrest and flank sediments from $10^{\circ} \mathrm{S}$ [Heath and Dymond, 1981; Schaller et al., 2000] indicate that the oxic surface layer at this site must always have been thick enough to trap a significant proportion of the upwardly diffusing Mn within the sediment for most of the 
last $740 \mathrm{ka}$. This is in contrast to sediment records from $10^{\circ} \mathrm{S}, 34 \mathrm{~km}$ from the ridge axis, where significant $\mathrm{Mn}$ loss is observed below $4 \mathrm{cmbsf}(\mathrm{Mn} / \mathrm{Fe}=0.17-0.33$; [Schaller et al., 2000]). There is no Mn redox cycling apparent in oxic sediments from the same latitude east of the ridge axis; sedimentary $\mathrm{Mn} / \mathrm{Fe}$ ratios are relatively constant and no measurable $\mathrm{Mn}^{2+}$ is observed in pore waters [Dunk and Mills, 2006] although inferred carbon export and bottom water oxygen [Fiedler and Talley, 2006] is similar east and west of the ridge axis at $15^{\circ} \mathrm{S}$. Thus the main control on redox status at the EPR sites is inferred to be the enhanced hydrothermal supply of reduced sulfide species on axis and the western flank that are subsequently oxidised in situ during early diagenesis.

Hydrothermally-derived Mo is associated with hydrothermal sulfides which are transported to the ridge-crest and flank sediments. In situ oxidation of sulfides releases Mo to pore waters and the Mo content of post-oxic sediments is subsequently controlled by the redox cycling of $\mathrm{Mn}$ within the oxidation front [Schaller et al., 2000]. The molybdate oxyanion $\left(\mathrm{MoO}_{4}{ }^{2-}\right)$ has a high affinity for $\mathrm{MnO}_{2}$ and $\mathrm{Mo}$ is remobilised when the $\mathrm{MnO}_{2}$ substrate is reduced during early diagenesis [Shimmield and Price, 1986]. The $\mathrm{Mo} / \mathrm{Mn}$ ratio of oxic deep sea sediments and ferromanganese deposits is relatively constant (0.002; [Shimmield and Price, 1986]) and the average ratio for oxic sediments (with lower hydrothermal $\mathrm{Mn}$ content) from the eastern EPR flank at $15^{\circ} \mathrm{S}$ is 0.0016 [Dunk and Mills, 2006]. The Mo/Mn ratio at $15^{\circ} \mathrm{S}$ does not reach oxic values at any depth within the core (Fig. 4e). The hydrothermal supply of particulate Mn at this site [Feely et al., 1996] vastly exceeds the inferred Mo supply which is not adequate to achieve normal pelagic oxic $\mathrm{Mo} / \mathrm{Mn}$ ratios even within the upper oxic layers: $\mathrm{Mn}$ is significantly enriched throughout the core. The low downcore $\mathrm{Mo} / \mathrm{Mn}$ ratio indicates that 
significant Mn cycling (and preferential Mo loss) occurred while the core was relatively close to the ridge axis under post-oxic conditions and Mo remobilisation and accumulation in the upper core is apparent (Fig. 4e). The elevated Mo/Mn ratios in the upper core are consistent with a shift to more oxic sedimentary conditions with time which is inferred to relate to the distal accumulation of more oxidised hydrothermal material and an overall increase in Pacific ventilation and/or decrease in carbon export since the mid-Pleistocene transition [Venuti et al., 2007].

The active oxidation front in this core is inferred to be at $\sim 140 \mathrm{cmbsf}$ (120 kyr; Fig. 4e) based on the Mo distribution and the maximum inflection in the Mo/Mn profile. The shape of the Mo/Mn profile is consistent with progressive deepening of the oxidation front to $140 \mathrm{cmbsf}$ and Mo preferentially accumulates above oxidation front over time as continued Mo and Mn cycling occurs. Metastable remnants of relict Mo/Mn peaks are observed in MIS 7 and 9 (Fig 4e). Deep ( $>1 \mathrm{~m}$ ) oxidation fronts have previously been identified in Atlantic cores where non-steady state diagenesis is controlled by turbidite emplacement with additional organic carbon supply to the seafloor [Colley and Thomson, 1985] and deep oxygen penetration (several metres) is observed in hydrothermal sediments collected from the same latitude on the eastern flank of the EPR [Dunk and Mills, 2006]. Cores underlying the oligotrophic South Pacific gyre show oxygen penetration to basement ( $\sim 8 \mathrm{~m}$ depth; [Fischer et al., 2009]). The slow sediment accumulation in the upper core and the inferred low electron donor input relative to deeper in the core mean that while similar processes may well occur transiently at the end of MIS 2 (termination I), evidence for non-steady state redox cycling is not preserved in 
the upper sediment record and the active oxidation front has now penetrated to termination II (140 cmbsf).

Plume-derived hydrous $\mathrm{Fe}$ oxides which include ferrihydrite phases will undergo transformation during oxic and suboxic diagenesis to a range of more crystalline Fe rich phases [Dunk and Mills, 2006]. Phase transformation reactions exclude large cations and oxyanions from the more crystalline Fe oxide structures and diffusive transport and reaction of these elements can overprint the primary sedimentary record. The in situ oxidation of Fe sulfides by a range of electron donors including $\mathrm{O}_{2}, \mathrm{NO}_{3}{ }^{-}$and $\mathrm{MnO}_{2}$ [Aller and Rude, 1988] leads to ferrihydrite formation during early diagenesis and this ferrihydrite transforms to crystalline phases over time, further complicating the diagenetic history of this core.

\subsection{Trace metal diagenesis}

The U content in core GS7202-35 is extremely high compared with normal hydrothermal sediments (Fig. 5a) with maximum values found consistently in sediments laid down during glacial periods, and a peak of $30 \mathrm{ppm}$ at $6.33 \mathrm{mbsf}$ (443 kyr, MIS 12). Previously published ${ }^{234} \mathrm{U} /{ }^{238} \mathrm{U}$ ratios [Rydell et al., 1974] are within error of the age corrected seawater activity ratio (1.14 [Chen et al., 1986]) in the upper $4.5 \mathrm{~m}$ of the core, indicating a seawater origin for the sedimentary U. Uranium has been shown to be elevated on hydrothermal sulfide surfaces [Mills et al., 1994] and in sulfidic plume particles on the northern EPR [German et al., 2002]. Thus fine-grained plume-derived sulfides are a major source of $U$ input to metalliferous sediments. 
The Cd content is also significantly elevated throughout the core (10-40 ppm; Fig. 5b), reflecting the plume sulfide input at this site. Trans-Atlantic Geotraverse (TAG) plume sulfides have Cd contents of 10-500 ppm [Metz and Trefry, 1993] and in situ oxidation of sulfides will lead to $\mathrm{Cd}$ association with oxyhydroxide phases and retention in the sediment. Comparison with ridge-crest cores at $10^{\circ} \mathrm{S}$ [Schaller et al., 2000] implies that the Mo, $\mathrm{U}$ and $\mathrm{Cd}$ are all primarily sourced from sulfidic plume input and are variably mobile during suboxic diagenesis.

The U/Fe ratio for oxic ridge flank metalliferous sediments is relatively constant and low $\left(\mathrm{U} / \mathrm{Fe}=0.3 \times 10^{-4} ;\right.$ Mills et al., 1994] $)$ and the $\mathrm{U} / \mathrm{Fe}$ ratio is enhanced relative to this value throughout most of this core (Fig. 6a). At the active oxidation front (120 kyr), $U$ is inferred to have been relocated into the underlying glacial section by oxidation [Colley and Thomson, 1985]. Oxygen penetration and oxidation remobilises a fraction of plumederived $U$ that is reprecipitated as U(IV) below the oxidation front in MIS 6 (Fig. 6a). The U/Fe peaks in the upper oxic core are inferred to be non-steady state, metastable features that result from more recent hydrothermal sedimentation during MIS1-5. The decreased plume-derived electron donor supply as the core moves off axis and the slower sediment accumulation rate (Fig. 2c) allow oxygen burn down to MIS 6. The U/Fe ratio approaches the low oxic sedimentary value towards the end of MIS 6, 8, 10 and 12 (Fig. 6a) indicating that oxic burndown and redistribution of $U$ occurred after glacial terminations V, IV, III and II as the electron donor supply to the seafloor waned and/or the bottom water oxygen content increased during the following interglacial. Maximum $\mathrm{U} / \mathrm{Fe}$ ratios occur during glacial periods and in particular the largest peak occurs at $443 \mathrm{ka}$ in MIS 12 (Fig. 6a). This largest U/Fe peak coincides with the MIS 12 ventilation 
minimum in the South Pacific [Venuti et al., 2007] which is followed by the long, warm MIS 11 interglacial period. These mid-Pleistocene climatic extremes lead to maximal relocation of the deposited $\mathrm{U}$.

Diffusive uptake and fixation as U(IV) under suboxic conditions can conceivably lead to an influx of authigenic $\mathrm{U}$ in slowly accumulating sediments, but bioturbation and oxidation leads to net efflux of $U$ from the sediments [McManus et al., 2005]. Significant authigenic $\mathrm{U}$ accumulation by this mechanism only occurs in sediments where the redox interface is within a few $\mathrm{cm}$ of the surface [Morford et al., 2005]. The surface oxic layer thickness at $15^{\circ} \mathrm{S}$ is inferred to have exceeded $5 \mathrm{~cm}$ to retain the $\mathrm{Mn}$ (II) within the sediment throughout much of the last $740 \mathrm{kyr}$ and significant authigenic $\mathrm{U}$ uptake from seawater only occurs when the oxidation front is close to the sediment surface under glacial conditions. The main source of the $\mathrm{U}$ enrichment at $15^{\circ} \mathrm{S}$ is likely to be derived both from allochthonous inputs of seawater $\mathrm{U}$ associated with sulfidic plume particles [German et al., 2002] and enhanced by authigenic U uptake during glacial periods. The subsurface $U$ peaks record periods of non-steady state diagenesis and burn down associated with post glacial decrease in electron donor supply to the sediment which is associated with increasing bottom water oxygen content. This interpretation challenges the assertion by Rydell et al. [1974] and Schaller et al. [2002] that U enrichment along this sector of the EPR arises from subsurface fluid flow. The inferred variation in redox status and impact on the $\mathrm{Mo} / \mathrm{Mn}$ and $\mathrm{U} / \mathrm{Fe}$ ratios over glacial-interglacial cycles is summarised schematically in Fig. 7.

Phosphorus and K content covary downcore (Fig. 5c) and peaks occur in glacial stage sediments. Copper and V content also covary with depth and are inferred to be sourced 
from seawater and hydrothermal inputs and their distribution modified during early diagenesis (Fig. 5d, e). These trace metal profiles will be discussed in turn to develop an understanding of the diagenetic overprinting on the inferred primary hydrothermal input.

Phosphate is highly mobile during early diagenesis and the signature preserved is inferred to be a combination of the primary hydrothermal input overprinted by diagenetic processes. High $\mathrm{P} / \mathrm{Fe}$ ratios coincide with glacial periods and lower $\mathrm{P} / \mathrm{Fe}$ with interglacials (Fig. 6b). The low sedimentary P/Fe ratio at this site and at $10^{\circ} \mathrm{N}$ (Fig. 8) compared with SEPR plume particles $(\mathrm{P} / \mathrm{Fe}=0.1$ [Feely et al., 1996]) reflects the significant sulfidic plume input to this site of particles that have little affinity for seawater $\mathrm{PO}_{4}{ }^{3-}$ [Feely et al., 1996]. These low ratios are similar to $\mathrm{P} / \mathrm{Fe}$ ratios at other sites along the SEPR (0.055: [Marchig et al., 1986], 0.049: [Schaller et al., 2000], 0.044: [Poulton and Canfield, 2006]) which have also been attributed to dilution of plume-derived material with plume sulfides and $\mathrm{P}$ loss during oxic diagenesis that predominates in the upper sediment during interglacial periods. The higher glacial $\mathrm{P} / \mathrm{Fe}$ ratios are consistent with exposure to a nutrient-rich, oxygen-depleted water mass during these periods.

The close correlation between $\mathrm{P}$ and $\mathrm{K}$ at this site is striking and the most likely phase hosting $\mathrm{K}$ is hydrogenous Fe-hydroxyphosphates and minor phillipsite or other zeolite generated in situ during early diagenesis. However, there is no mineralogical evidence for the presence of any such crystalline phase in any abundance.

Barium in hydrothermal sediments is dominantly associated with the Fe oxyhydroxide fraction with additional contributions from carbonate bound barium and biogenic barite from the upper water column [Dymond et al., 1981]. The Ba/Fe ratio of the hydrothermal 
input at $14^{\circ} \mathrm{S}$ has been determined by sequential leach analysis of metalliferous sediments $(\mathrm{Ba} / \mathrm{Fe}=0.013$; Dunk et al., 2006) and the $\mathrm{Ba} / \mathrm{Fe}$ ratio of core $\mathrm{GS} 7202-35$ is consistently higher than this ratio (Fig. 6c) confirming the multiple sources of this element at this site. Low $\mathrm{Ba} / \mathrm{Fe}$ ratios are associated with the minima in $\mathrm{Mn} / \mathrm{Fe}$ (Fig. $4 \mathrm{~d}$ ) and regions of $\mathrm{U}$ relocation (Fig. 6a) which are relict oxidation fronts suggesting that $\mathrm{Ba}$ has been significantly redistributed during $\mathrm{Mn}$ and $\mathrm{Fe}$ recycling at this site and therefore cannot be used as a productivity proxy in this setting.

Other redox-sensitive metals such as $\mathrm{Cu}$ and $\mathrm{V}$ are dominantly controlled by the recycling of $\mathrm{MnO}_{2}$ (Fig. 6d, e). Elevated $\mathrm{Cu} / \mathrm{Fe}$ and $\mathrm{V} / \mathrm{Fe}$ ratios correlate with maximum $\mathrm{Mn} / \mathrm{Fe}$ ratios downcore and the relict oxidation fronts indicated by minimum $\mathrm{Mn} / \mathrm{Fe}$ ratios correlate with minima in the $\mathrm{Cu} / \mathrm{Fe}$ and $\mathrm{V} / \mathrm{Fe}$ profiles. Redox cycling of $\mathrm{MnO}_{2}$ releases $\mathrm{Cu}$ and $\mathrm{V}$ to pore fluids and they accumulate preferentially in the oxic interglacial regions overlying the active and relict oxidation fronts. The correspondence between low $\mathrm{Mn} / \mathrm{Fe}$ and $\mathrm{V} / \mathrm{Fe}$ ratios has previously been seen at $10^{\circ} \mathrm{S}$ where low $\mathrm{V} / \mathrm{Fe}$ ratios are associated with Mn loss from the suboxic ridge crest sediments [Schaller et al., 2000].

\subsection{Mechanisms for changing depth of the oxidation front}

There are three main controls on the depth of oxidation front: bottom water oxygen content, electron donor supply, and sedimentation rate. We have demonstrated that sediment accumulation at this site does not control the observed non-steady state diagenesis at terminations V, IV, III and II (Section 3.1; Fig. 2c). Comparison of the suboxic sediment record at $15^{\circ} \mathrm{S}$ with elemental ratios for fully oxic sediments collected at the same latitude east of the ridge axis [Dunk and Mills, 2006] demonstrate the impact 
of plume-derived electron donors to the seafloor at this latitude. Hydrothermally-derived electron donors have a major impact on the redox state of sediments in this region.

Studies of productivity proxies at $5^{\circ} \mathrm{S}$ in the SE Pacific across glacial cycles including MIS 11 and 12 suggest no systematic change in export production through time but instead identify significant shifts in lysocline depth and carbonate preservation [Murray et al., 2000; Anderson et al., 2008] that are due to differences in bottom water carbonate ion activity related to ocean circulation changes at $\sim 4200 \mathrm{~m}$ water depth. The ridge flank setting of the core studied here is well above the modern lysocline depth of $\sim 3500 \mathrm{~m}$ and significant carbonate dissolution is unlikely. Records from the equatorial Pacific imply that pulses of enhanced export occurred during glacial terminations [Martinez and Robinson, 2010]. Thus the primary control on oxidation front depth on the ridge flank at $15^{\circ} \mathrm{S}$ is likely to be glacial-interglacial changes in bottom water ventilation and oxygen content which in turn controls the supply of hydrothermal sulfides to the sediment moderated by short term pulses in carbon export to the seafloor during glacial terminations. The low $\mathrm{CaCO} 3$ levels in MIS 11 sediments suggest that carbonate dissolution may also occur in the surficial sediments at this time. It is not possible to quantify this dissolution effect, but it would be expected to have an effect similar to a decrease in accumulation rate in that it would lead to an increase in the oxidation depth in the sediments enhancing the apparent $\mathrm{U}$ accumulation.

Lower glacial oxygen levels lead to a shoaling of the redoxcline in the sediment and increased accumulation of plume-derived sulfides and associated metals at the seafloor. Pulses of enhanced carbon export during glacial terminations lead to a shallow redoxcline. Mn cycling below the oxidation front leads to remobilisation of 
oxyhydroxide bound metals $(\mathrm{Mo}, \mathrm{Cu}, \mathrm{V})$ and reaccumulation above the oxidation front. Subsequent systematic deepening of the oxidation front occurs after glacial terminations $\mathrm{V}$, IV, III and II, relocating the plume-derived $\mathrm{U}$ into the deeper suboxic sediment. Oxidation of the remnant plume-derived sulfides in situ provides a reactive ferrihydrite phase that effectively sorbs elements released during $\mathrm{Fe}$ oxide transformation reactions.

One test of this hypothesis is comparison with data from other EPR locations with documented subsurface U enrichments (Fig. 1). Few EPR cores have a Pleistocene age model and only two records have appropriate down-core sample resolution [Schaller et al., 2000; Shimmield and Price, 1988]. The former includes multi-element data and a comparable sediment accumulation rate $\left(\sim 1.4 \mathrm{~cm} \mathrm{kyr}^{-1}\right.$; [Schaller et al., 2000]) which can be compared with our data set (Fig. 8). Downcore depth profiles of $\mathrm{U} / \mathrm{Fe}$ and $\mathrm{P} / \mathrm{Fe}$ for the upper $\sim 2 \mathrm{~m}$ provide a record back to MIS 6 where the glacial age U and P peaks can be correlated between the two sites (Fig. 8) supporting the case for a wider scale impact. The $10^{\circ} \mathrm{S}$ core is significantly more reducing (inferred active oxidation front at $\sim 4 \mathrm{cmbsf}$ ) than the $15^{\circ} \mathrm{S}$ core because it is closer to the ridge axis (higher sulfide electron donor input) and underlies more productive waters at the periphery of the gyre. Thus the U/Fe ratios are higher (more U-rich sulfides supplied to sediment, less oxygen burn down and remobilisation of $\mathrm{U}$ ) whereas the $\mathrm{P} / \mathrm{Fe}$ ratios are similar to $15^{\circ} \mathrm{S}$. The upper core record at $10^{\circ} \mathrm{S}$ is dominated by redox cycling and metal flux (Mo, Mn, V) to the overlying water column [Schaller et al., 2000]. The high precision organic carbon record for the $10^{\circ} \mathrm{S}$ site (Fig. 8) is consistent with glacial shallowing of the oxidation front and enhanced preservation of the organic carbon flux to the seafloor during these periods. 
Comparisons with other cores are more problematic for the reasons stated above. For example, $\mathrm{U}$ peaks observed at $20^{\circ} \mathrm{S}$ previously attributed to enhanced hydrothermal scavenging [Shimmield and Price, 1988] are hypothesised to be associated with termination I deglaciation but in the absence of any Fe data and a poorly constrained age model this is impossible to test without resampling the archived cores. Comparisons with NW Pacific climate records from a similar depth (3244 m) suggest that glacial deepening of the oceanic respired carbon pool is a widespread phenomenon in the Pacific [Jaccard et al., 2009].

\section{Conclusions}

New paleoceanographic records from the SE Pacific show that MIS 12, 10, 8 and 6 were associated with significant reduction in ocean ventilation at ridge crest depth $(\sim 3000 \mathrm{~m})$, followed by a recharge of the bottom water with more oxygenated water after glacial terminations V, IV, III and II. This variation in ocean ventilation leads to changes in electron donor (hydrothermal sulfide) supply to the sediment that is moderated by enhanced carbon export during glacial terminations.

The large hydrothermal plume at $15^{\circ} \mathrm{S}$ on the EPR is inferred to have delivered variable and decreasing amounts of particulate sulfide to the core site as it moved off axis over the last $740 \mathrm{ka}$. The main control on sedimentary accumulation of hydrothermal sulfide particles is distance from the hydrothermal source and bottom water oxygen content which in turn also controls the depth of the transition metal oxidation fronts in the sediment and the exposure time to oxidation at the seafloor. As a result only trace sulfide is now found in the sediment, and the transitory presence of sulfides in the sediments has 
been inferred from the very high contents of the chalcophile elements $\mathrm{Cu}, \mathrm{Cd}$, and $\mathrm{U}$. In situ oxidation of sulfides and authigenic $\mathrm{U}$ uptake leads to further overprinting the inferred primary hydrothermal signature.

After glacial terminations V, IV, III and II the ridge-crest depth Pacific is inferred to be ventilated with higher oxygen content seawater and the active oxidation front progressively burns down during interglacial periods into the underlying glacial deposits modifying the $\mathrm{Mn}, \mathrm{Ba}, \mathrm{Cu}, \mathrm{V}$ and $\mathrm{U}$ distributions. Suboxic ridge-crest metalliferous sediments thus provide a Pleistocene history of past bottom water oxygen in a region that has sparse palaeoceanographic records.

Published sedimentary records from the southern EPR from $10^{\circ} \mathrm{S}$ through to $20^{\circ} \mathrm{S}$ exhibit subsurface $\mathrm{U}$ (and in some cases documented P) peaks that are largely undated (Fig. 1). We demonstrate that these subsurface peaks may also be relicts of the basin-wide changes in glacial SE Pacific ventilation, but this hypothesis remains to be tested through determination of good sediment chronologies for each site and multi-element analysis at an appropriate spatial resolution. 


\section{Acknowledgements}

Larry Peterson is thanked for providing access to samples and for resampling core GS7202-35. Darryl Green, Ian Croudace, Andy Milton and Mike Bolshaw are thanked for their assistance with geochemical analyses at NOCS. SLT was funded by NERC studentship NER/S/A/2003/11858. We are particularly grateful to Simon Poulton and Rachel Dunk for stimulating discussions during the development of this work and to Gerald Dickens, Jess Adkins and three anonymous reviewers for extremely constructive reviews and comments. 
Figure Captions

Figure 1: Map of Southern East Pacific Rise showing coring location at $15^{\circ} \mathrm{S}$ (GS7202-35 [Rydell et al., 1974]). Ridge axis cores with subsurface U enrichments are shown (Y-717-53P [Dymond, 1981; Schaller et al., 2000], RIS65 and 69 [Veeh and Boström, 1971], EXCO [Dunk and Mills, 2006], V19-54 [Bender et al., 1971], 154-18 [Shimmield and Price, 1988] along with the coring location for DSDP Leg 92, hole 598 [Poulton and Canfield, 2006].

Figure 2: Plots of (a) the $\delta^{18} \mathrm{O}$ for the benthic foraminifera composite (grey line) [Shackleton et al., 1990] with the bulk $\delta^{18} \mathrm{O}$ data for this study (black dots and solid line), (b) the bulk $\delta^{13} \mathrm{C}$ composition for ODP leg 138 eastern equatorial Pacific (grey line) [Shackleton and Hall, 1995] with the bulk $\delta^{13} \mathrm{C}$ data for this study (black dots and solid line), (c) the Linear Sedimentation Rate (LSR) inferred from the age model presented in (a). Distance from ridge axis is estimated from sediment age and spreading rates [Grevemeyer et al., 2002]. Grey shading indicates glacial stages, numbers indicate marine isotope stages (MIS [Imbrie et al., 1984]).

Figure 3: Plot of $\mathrm{Fe}(\%), \mathrm{Mn}(\%), \mathrm{Si}(\%)$ and $\mathrm{Al}(\%)$ against $\mathrm{CaCO}_{3}$ content for core GS7202-35.

Figure 4: Plot of (a) $\mathrm{CaCO}_{3}$, (b) Fe, (c) $\mathrm{Mn}$, (d) $\mathrm{Mn} / \mathrm{Fe}$ ratio and (e) $\mathrm{Mo} / \mathrm{Mn}$ ratio against age. Dashed horizontal lines indicate the endmember hydrothermal $\mathrm{Mn} / \mathrm{Fe}$ ratio for Nazca Plate ridge crest sediments [Dymond, 1981] and oxic sediment $\mathrm{Mo} / \mathrm{Mn}$ ratio 
[Shimmield and Price, 1986; Dunk and Mills, 2006]. Arrows indicate glacial terminations and the active and relict oxidation fronts (see text).

Figure 5: Plot of (a) U against age, (b) Cd against age, (c) P (open circles) and K (filled circles) against age, (d) $\mathrm{Cu}$ against age and (e) V against age. All shading as for Fig. 2.

Figure 6: Elemental ratio plots for core GS7202-35 plotted against age. (a) U/Fe ratio (g/g), (b) $\mathrm{P} / \mathrm{Fe}$ ratio (g/g), (c) $\mathrm{Ba} / \mathrm{Fe}$ ratio, (d) $\mathrm{V} / \mathrm{Fe}$ ratio (g/g), and (e) $\mathrm{Cu} / \mathrm{Fe}$ ratio (g/g). Arrows indicate regions of $\mathrm{U}$ burn down and the active and relict oxidation fronts (see text). Dashed lines indicate the $\mathrm{U} / \mathrm{Fe}$ ratio for oxic metalliferous sediments [Mills et al., 1994], $\mathrm{Ba} / \mathrm{Fe}$ for the plume-derived component of EXCO sediments [Dunk and Mills, 2006], V/Fe for oxic EPR sediments [Dunk and Mills, 2006], $\mathrm{Cu} / \mathrm{Fe}$ for the oxic SEPR endmember [Dymond, 1981] and oxic EPR sediments [Dunk and Mills, 2006]. Shaded area in (b) indicates the range in observed $\mathrm{P} / \mathrm{Fe}$ for SEPR sediments (see text). All other shading as for Fig. 2.

Figure 7: Schematic representation of pore water and solid phase response to an interglacial-glacial-interglacial transition through time from left to right. Interglacial oxygen penetration is relatively deep and $\mathrm{Mn}^{2+}$, and other redox-sensitive metals and those associated with Fe-Mn oxyhydroxide phases, are recycled below this depth. The glacial shift to a shallower oxidation front leads to significant Mn and Mo remobilisation from the solid phase and relocation of these elements above the new oxidation front. Differential mobility of Mn and Mo, and the significant hydrothermal Mn input at this site, leads to variable $\mathrm{Mo} / \mathrm{Mn}$ ratios within the shallow oxic zone. Lower bottom water oxygen levels and a shallower oxidation front lead to enhanced plume U supply to the 
seafloor during glacial periods. Glacial termination is inferred to be associated with a pulse of carbon supply to the seafloor that shallows the oxidation front further [Martinez and Robinson, 2010]. Subsequent deepening of the oxidation front during interglacial periods leads to oxygen burn down and relocation of the plume-derived $U$ below the oxidation front.

Figure 8: Comparison of $\mathrm{U} / \mathrm{Fe}$ and $\mathrm{P} / \mathrm{Fe}$ ratios downcore from (a) $10^{\circ} \mathrm{S}$ [Schaller et al., 2000] and (b) the present study. High precision organic carbon data for the $10^{\circ} \mathrm{S}$ site are plotted (dashed line). Shading indicates glacial periods for the $15^{\circ} \mathrm{S}$ core determined from the age model (Fig. 2a). 


\section{References}

Aller, R. C., and P. D. Rude, Complete oxidation of solid-phase sulfides by manganese and bacteria in anoxic marine sediments, Geochimica et Cosmochimica Acta, 52, 751$765,1988$.

Anderson, R. F., M. Q. Fleisher, Y. Lao, and G. Winckler, Modern $\mathrm{CaCO}_{3}$ preservation in equatorial Pacific sediments in the context of late-Pleistocene glacial cycles, Marine Chemistry, 111, 30-46, 2008.

Bender, M., W. Broecker, V. Gornitz, U. Middel, R. Kay, S.-S. Sun, and P. Biscaye, Geochemistry of three cores from the East Pacific Rise, Earth and Planetary Science Letters, 12, 425-433, 1971.

Boyle, E. A., Vertical oceanic nutrient fractionation and glacial/interglacial $\mathrm{CO}_{2}$ cycle, Nature, 331, 55-56, 1988.

Boyle, E. A., Cadmium and $\delta^{13} \mathrm{C}$ paleochemical ocean distribution during the stage 2 glacial maximum, Annu. Rev. Earth Planet. Sci., 20, 245-287, 1992.

Broecker, W. S., and G. H. Denton, The role of ocean-atmosphere reorganizations in glacial cycles, Geochimica et Cosmochimica Acta, 53, 2465-2501, 1989.

Chen, J. H., R. L. Edwards, and G. J. Wasserburg, U-238,U-234 and Th-232 in seawater, Earth and Planetary Science Letters, 80, 241-251, 1986.

Colley, S., and J. Thomson, Recurrent uranium relocations in distal turbidites emplaced in pelagic conditions, Geochimica Et Cosmochimica Acta, 49, 2339-2348, 1985.

Dunk, R. M., and R. A. Mills, The impact of oxic alteration on plume-derived transition metals in ridge flank sediments from the East Pacific Rise, Marine Geology, 229, 133$157,2006$.

Dymond, J., Geochemistry of Nazca Plate surface sediments - an evaluation of hydrothermal, biogenic, detrital and hydrogenous sources, Geological Society of America Memoir, 154, 133-173, 1981.

Edmonds, H. N., and C. R. German, Particle geochemistry in the Rainbow hydrothermal plume, Mid-Atlantic Ridge, Geochimica et Cosmochimica Acta, 68, 759-772, 2004. 
Feely, R. A., E. T. Baker, K. Marumo, T. Urabe, J. Ishibashi, J. Gendron, G. T. Lebon, and K. Okamura, Hydrothermal plume particles and dissolved phosphate over the superfast-spreading southern East Pacific Rise, Geochimica et Cosmochimica Acta, 60, 2297-2323, 1996.

Fiedler, P. C., and L. D. Talley, Hydrography of the eastern tropical Pacific: A review, Progress in Oceanography, 69, 143-180, 2006.

Fischer, J. P., T. G. Ferdelman, S. D’Hondt, H. Røy, and F. Wenzhofer, Oxygen penetration deep into the sediment of the South Pacific gyre, Biogeosciences, 6, 1467$1478,2009$.

Galbraith, E. D., S. L. Jaccard, T. F. Pedersen, D. M. Sigman, G. H. Haug, M. Cook, J. R. Southon and R. Francois, Carbon dioxide release from the North Pacific abyss during the last deglaciation, Nature, 449, 890-894, 2007.

German, C. R., S. Colley, M. R. Palmer, A. Khripounoff, and G. P. Klinkhammer, Hydrothermal plume-particle fluxes at 13 degrees $\mathrm{N}$ on the East Pacific Rise, Deep-Sea Research Part I-Oceanographic Research Papers, 49, 1921-1940, 2002.

Grevemeyer, I., B. Schramm, C. W. Devey, D. S. Wilson, B. Jochum, J. Hauschild, K. Aric, H. W. Villinger, and W. Weigel, A multibeam-sonar, magnetic and geochemical tow-line survey at 14o14'S on the southern East Pacific Rise - insights into the fourth dimension of ridge crest segmentation, Earth and Planetary Science Letters, 199, 359$372,2002$.

Hauschild, J., I. Grevemeyer, N. Kaul, and H. Villinger, Asymmetric sedimentation on young ocean floor at the East Pacific Rise, 15 degrees S, Marine Geology, 193, 49-59, 2003.

Heath, G. R., and J. Dymond, Metalliferous-sediment deposition in time and space - East Pacific Rise and Bauer Basin, Northern Nazca Plate, Geological Society of America Memoirs, 154, 175-197, 1981.

Imbrie, J., J. D. Hays, D. G. Martinson, A. McIntyre, A. C. Mix, J. J. Morley, N. G. Pisias, W. L. Prell, and N. J. Shackleton, The orbital forcing theory of Pleistocene climate: Support for a revised chronology of the marine ${ }^{18} \mathrm{O}$ isotope record. in Milankovitch and Climate Part 1, edited by Berger, A., J. Imbrie, J. Hays, G. Kukla and B. Saltzman, pp. 269-305, D Reidel Publishing Company, 1984. 
Jaccard, S. L., E. D. Galbraith, D. M. Sigman, G. H. Huag, R. Francois, and T. F. Pedersen, Subarctic Pacific evidence for a glacial deepening of the oceanic respired carbon pool, Earth and Planetary Science Letters, 277, 156-165, 2009.

Lupton, J.E., and H. Craig, A Major He-3 Source at 15-Degrees-S on the East Pacific Rise, Science, 214, 13-18, 1981.

Marchig, V., J. Erzinger, and P. M. Heinze, Sediment in the black smoker area of the East Pacific Rise (18.5 Degrees-S), Earth and Planetary Science Letters, 79, 93-106, 1986.

Martinez, P., and R. S. Robinson, Increase in water column denitrification during the last deglaciation: the influence of oxygen demand in the eastern equatorial Pacific, Biogeosciences, 7, 1-9, 2010.

Matsumoto, K., T. Oba, J. Lynch-Stieglitz, and H. Yamamoto, Interior hydrography and circulation of the glacial Pacific Ocean, Quaternary Science Reviews, 21, 1693-1704, 2002.

McManus, J., W. M. Berelson, G. P. Klinkhammer, D. E. Hammond, and C. Holm, Authigenic uranium: relationship to oxygen penetration depth and organic carbon rain, Geochimica et Cosmochimica Acta, 69, 95-108, 2005.

Metz, S., and J. H. Trefry, Field and laboratory studies of metal uptake and release by hydrothermal precipitates, Journal of Geophysical Research-Solid Earth, 98, 9661-9666, 1993.

Mills, R. A., and H. Elderfield, Hydrothermal activity and the geochemistry of metalliferous sediment, AGU Monograph, 92, 391-407, 1995.

Mills, R. A., J. Thomson, H. Elderfield, R. W. Hinton, and E. Hyslop, Uranium enrichment in metalliferous sediments from the Mid-Atlantic Ridge, Earth and Planetary Science Letters, 124, 35-47, 1994.

Mills, R. A., and R. M. Dunk, Tracing low-temperature fluid flow on ridge flanks with sedimentary uranium distribution, Geochem. Geophys. Geosyst., 11, Q08009, doi:10.1029/2010GC003157, 2010.

Morford, J. L., S. R. Emerson, E. J. Breckel, and S. H. Kim, Diagenesis of oxyanions (V, $\mathrm{U}, \mathrm{Re}$, and Mo) in pore waters and sediments from a continental margin, Geochimica et Cosmochimica Acta, 69, 5021-5032, 2005. 
Murray, R. W., C. Knowlton, M. Leinen, A. C. Mix, and C. H. Polsky, Export production and carbonate dissolution in the central Equatorial Pacific Ocean over the past $1 \mathrm{Myr}$, Paleoceanography, 15, 570-592, 2000.

Okazaki, Y., A. Timmermann, L. Menviel, N. Harada, A. Abe-Ouchi, M.O. Chikamoto, A. Mouchet and H. Asahi, Deepwater formation in the North Pacific during the last glacial termination, Science, 329, 200-204, 2010.

Paillard, D., L. Labeyrie, and P. Yiou, Macintosh programme performs time series analysis., EOS, Trans. Amer. Geophys. U., 77, 379, 1996.

Poulton, S. W., and D. E. Canfield, Co-diagenesis of iron and phosphorus in hydrothermal sediments from the southern East Pacific Rise: Implications for the evaluation of paleoseawater phosphate concentrations, Geochimica et Cosmochimica Acta, 70, 5883-5898, 2006.

Reid, J. L., Evidence of an effect of heat-flux from the East Pacific Rise upon the characteristics of the mid-depth waters, Geophysical Research Letters, 9, 381-384, 1982. Rydell, H., T. Kraemer, K. Bostrom, and O. Joensuu, Postdepositional injections of uranium-rich solutions into East Pacific Rise sediments, Marine Geology, 17, 151-164, 1974.

Schaller, T., J. Morford, S. R. Emerson, and R. A. Feely, Oxyanions in metalliferous sediments: Tracers for paleoseawater metal concentrations?, Geochimica et Cosmochimica Acta, 64, 2243-2254, 2000.

Schippers, A., and B. B. Jørgensen, Oxidation of pyrite and iron sulfide by manganese dioxide in marine sediments, Geochimica et Cosmochimica Acta, 65, 915-922, 2001.

Schramm, B., C. W. Devey, K. M. Gillis, and K. Lackschewitz, Quantitative assessment of chemical and mineralogical changes due to progressive low-temperature alteration of East Pacific Rise basalts from 0 to 9 Ma, Chemical Geology, 218, 281-313, 2005.

Shackleton, N. J., A. Berger, and W. R. Peltier, An alternative astronomical calibration of the lower Pleistocene time scale based on ODP site 677, Trans. R. Soc. Edinburgh: Earth Sci., 81, 251-261, 1990.

Shackleton, N. J., and M. A. Hall, Stable isotope records in bulk sediments (Leg 138). in Proc. ODP, Sci. Results, edited by Pisias, N. G., L. A. Mayer, T. R. Janecek, A. Palmer- 
Julson and T. H. van Andel, pp. 797-805, Ocean Drilling Program, College Station, TX, 1995.

Shimmield, G. B., and N. B. Price, The behavior of molybdenum and manganese during early sediment diagenesis - offshore Baja-California, Mexico, Marine Chemistry, 19, 261-280, 1986.

Shimmield, G. B., and N. B. Price, The scavenging of U, Th-230 and Pa-231 during pulsed hydrothermal activity at 20-Degrees-S, East Pacific Rise, Geochimica et Cosmochimica Acta, 52, 669-677, 1988.

Sigman, D. M., and E. A. Boyle, Glacial/interglacial variations in atmospheric carbon dioxide, Nature, 407, 859-869, 2000.

Stott, L., J. Southon, A. Timmermann and A. Koutavas, Radiocarbon age anomaly at intermediate water depth in the Pacific Ocean during the last deglaciation, Paleoceanography, 24, PA2223, doi:10.1029/2008PA001690.

Thomson, J., N. C. Higgs, and S. Colley, Diagenetic redistributions of redox-sensitive elements in northeast Atlantic glacial/interglacial transition sediments, Earth and Planetary Science Letters, 139, 365-377, 1996.

Thomson, J., N. C. Higgs, I. Jarvis, D. J. Hydes, S. Colley, and T. R. S. Wilson, The behavior of manganese in Atlantic carbonate sediments, Geochimica et Cosmochimica Acta, 50, 1807-1818, 1986.

Trocine, R. P., and J. H. Trefry, Distribution and chemistry of suspended particles from an active hydrothermal vent site on the Mid-Atlantic Ridge at 26-degrees-N, Earth and Planetary Science Letters, 88, 1-15, 1988.

Veeh, H., and K. Boström, Anomalous ${ }^{234} \mathrm{U}{ }^{238} \mathrm{U}$ on the East Pacific Rise, Earth and Planetary Science Letters, 10, 372-374, 1971.

Venuti, A., F. Florindo, E. Michel, and I. R. Hall, Magnetic proxy for the deep (Pacific) western boundary current variability across the mid-Pleistocene climate transition, Earth and Planetary Science Letters, 259, 107-118, 2007.

Yang, Y. L., H. Elderfield, T. F. Pedersen, and M. Ivanovich, Geochemical record of the Panama Basin during the Last Glacial Maximum carbon event shows that the glacial ocean was not suboxic, Geology, 23, 1115-1118, 1995. 


\begin{tabular}{|c|c|c|c|c|c|c|c|c|}
\hline Depth (cm) & Age (ka) & $\mathrm{Fe}(\%)$ & $M n(\%)$ & $\mathrm{Ca}(\%)$ & Al (ppm) & Si (\%) & $\mathbf{P}(\%)$ & $\mathrm{U}(\mathrm{ppm})$ \\
\hline 5.25 & 4.5 & 5.92 & 1.68 & 28.5 & 700 & 1.34 & 0.286 & 5.0 \\
\hline 15.5 & 13.3 & 4.97 & 1.50 & 29.7 & 738 & 1.29 & 0.292 & 7.1 \\
\hline 20.5 & 18.3 & 5.84 & 1.65 & 28.1 & 670 & 1.33 & 0.314 & 6.7 \\
\hline 25.5 & 22.8 & 4.69 & 1.71 & 29.6 & 733 & 1.14 & 0.244 & 4.8 \\
\hline 30.5 & 27.3 & 5.74 & 2.06 & 28.6 & 830 & 1.37 & 0.324 & 5.0 \\
\hline 35.5 & 31.8 & 6.33 & 2.31 & 27.7 & 801 & 1.47 & 0.407 & 8.2 \\
\hline 40.5 & 36.3 & 5.30 & 1.96 & 28.6 & 691 & 1.26 & 0.347 & 8.5 \\
\hline 45.5 & 40.8 & 4.89 & 1.78 & 29.5 & 742 & 1.22 & 0.286 & 8.2 \\
\hline 50.5 & 45.3 & 4.96 & 1.78 & 29.9 & 746 & 1.23 & 0.287 & 8.3 \\
\hline 55.5 & 49.8 & 5.14 & 1.81 & 29.7 & 763 & 1.30 & 0.311 & 8.1 \\
\hline 60.5 & 54.4 & 5.69 & 1.97 & 28.6 & 792 & 1.47 & 0.372 & 8.3 \\
\hline 65.5 & 58.9 & 6.15 & 2.14 & 28.0 & 704 & 1.38 & 0.403 & 8.2 \\
\hline 70.5 & 63.4 & 6.04 & 2.26 & 28.2 & 717 & 1.35 & 0.375 & 7.4 \\
\hline 75.5 & 67.9 & 5.96 & 2.21 & 28.7 & 771 & 1.35 & 0.343 & 7.3 \\
\hline 80.5 & 72.4 & 5.83 & 2.07 & 28.8 & 830 & 1.31 & 0.307 & 4.7 \\
\hline 85.5 & 76.9 & 6.04 & 2.13 & 28.4 & 851 & 1.34 & 0.289 & 4.9 \\
\hline 90.5 & 81.4 & 5.99 & 2.16 & 28.7 & 818 & 1.30 & 0.260 & 3.7 \\
\hline 95.5 & 85.9 & 6.37 & 2.43 & 27.8 & 805 & 1.37 & 0.282 & 5.7 \\
\hline 100.5 & 90.4 & 5.88 & 2.27 & 28.8 & 729 & 1.25 & 0.261 & 5.0 \\
\hline 115.5 & 103.9 & 6.01 & 2.18 & 28.6 & 746 & 1.31 & 0.281 & 5.2 \\
\hline 120.5 & 108.4 & 6.76 & 2.54 & 27.5 & 822 & 1.38 & 0.286 & 5.4 \\
\hline 125.5 & 113 & 6.17 & 2.34 & 28.2 & 860 & 1.30 & 0.258 & 4.1 \\
\hline 135.5 & 121.9 & 5.88 & 2.12 & 28.6 & 969 & 1.28 & 0.241 & 3.6 \\
\hline 138 & 123.9 & 5.59 & 1.99 & 29.0 & 910 & 1.19 & 0.222 & 4.0 \\
\hline 140.5 & 126 & 5.78 & 1.92 & 29.0 & 914 & 1.21 & 0.222 & 4.0 \\
\hline 143 & 128 & 5.69 & 1.93 & 29.1 & 885 & 1.20 & 0.224 & 6.0 \\
\hline 145.5 & 130 & 6.13 & 1.95 & 28.5 & 927 & 1.34 & 0.262 & 3.5 \\
\hline 148 & 132.1 & 6.72 & 2.10 & 28.3 & 897 & 1.27 & 0.279 & 8.3 \\
\hline 153 & 136.1 & 6.42 & 2.07 & 27.9 & 872 & 1.35 & 0.337 & 8.6 \\
\hline 155.5 & 138.2 & 5.53 & 1.88 & 29.1 & 801 & 1.27 & 0.325 & 8.3 \\
\hline 158 & 140.2 & 5.62 & 1.96 & 30.0 & 834 & 1.17 & 0.304 & 11.3 \\
\hline 160.5 & 142.2 & 5.10 & 1.87 & 29.5 & 797 & 1.23 & 0.331 & 8.6 \\
\hline 163 & 144.3 & 5.59 & 2.01 & 28.5 & 855 & 1.32 & 0.386 & 12.6 \\
\hline 165.5 & 146.3 & 5.95 & 2.14 & 28.1 & 784 & 1.39 & 0.466 & 11.3 \\
\hline 168 & 148.3 & 6.25 & 2.14 & 27.6 & 738 & 1.39 & 0.501 & 12.6 \\
\hline 178 & 156.5 & 5.91 & 2.21 & 28.0 & 717 & 1.34 & 0.463 & 11.9 \\
\hline 188 & 164.6 & 4.98 & 1.99 & 29.5 & 754 & 1.18 & 0.294 & 8.2 \\
\hline 193 & 168.7 & 5.05 & 1.96 & 30.4 & 733 & 1.06 & 0.241 & 6.9 \\
\hline 198 & 172.7 & 4.91 & 2.04 & 29.7 & 746 & 1.14 & 0.247 & 5.6 \\
\hline 203 & 176.8 & 4.89 & 2.06 & 29.7 & 742 & 1.12 & 0.231 & 5.7 \\
\hline 208 & 180.9 & 5.23 & 2.18 & 30.0 & 834 & 1.20 & 0.263 & 4.3 \\
\hline 213 & 184.9 & 5.08 & 2.06 & 29.4 & 733 & 1.17 & 0.278 & 4.8 \\
\hline 223 & 191 & 5.70 & 2.20 & 29.5 & 746 & 1.11 & 0.272 & 6.1 \\
\hline 228 & 194.1 & 5.49 & 2.15 & 30.1 & 729 & 1.04 & 0.226 & 4.7 \\
\hline 233 & 197.1 & 6.14 & 2.48 & 28.8 & 965 & 1.35 & 0.275 & 4.3 \\
\hline 238 & 200.2 & 6.47 & 2.72 & 28.3 & 897 & 1.37 & 0.299 & 4.3 \\
\hline 243 & 203.3 & 5.85 & 2.37 & 29.5 & 750 & 1.09 & 0.236 & 4.5 \\
\hline 248 & 206.3 & 6.32 & 2.53 & 28.8 & 944 & 1.26 & 0.273 & 5.8 \\
\hline 253 & 209.4 & 5.71 & 2.32 & 29.6 & 960 & 1.14 & 0.233 & 3.6 \\
\hline 258 & 212.4 & 5.62 & 2.31 & 29.4 & 1032 & 1.21 & 0.237 & 4.3 \\
\hline 263 & 215.5 & 5.63 & 2.34 & 29.8 & 805 & 1.12 & 0.243 & 4.3 \\
\hline 268 & 218.5 & 5.87 & 2.80 & 28.6 & 906 & 1.34 & 0.333 & 5.3 \\
\hline 273 & 221.6 & 5.79 & 2.52 & 29.1 & 733 & 1.12 & 0.312 & 6.3 \\
\hline
\end{tabular}




\begin{tabular}{|c|c|c|c|c|c|c|c|c|}
\hline 278 & 224.6 & 6.12 & 2.62 & 29.1 & 691 & 1.11 & 0.310 & 5.7 \\
\hline 283 & 227.7 & 5.39 & 2.48 & 29.8 & 754 & 1.13 & 0.246 & 3.5 \\
\hline 288 & 230.7 & 5.87 & 2.99 & 29.5 & 712 & 1.05 & 0.216 & 4.3 \\
\hline 293 & 233.8 & 6.66 & 2.44 & 28.8 & 633 & 1.15 & 0.263 & 3.5 \\
\hline 298 & 236.8 & 7.38 & 2.57 & 28.0 & 574 & 1.24 & 0.324 & 6.0 \\
\hline 303 & 239.9 & 7.71 & 2.69 & 27.6 & 624 & 1.33 & 0.324 & 8.0 \\
\hline 308 & 242.9 & 4.43 & 1.55 & 31.7 & 591 & 0.92 & 0.211 & 8.1 \\
\hline 313 & 246 & 4.64 & 1.75 & 30.7 & 775 & 1.19 & 0.287 & 11.3 \\
\hline 318 & 249 & 4.40 & 1.60 & 30.5 & 662 & 1.07 & 0.231 & 7.5 \\
\hline 333 & 258.2 & 4.27 & 1.63 & 30.5 & 696 & 1.13 & 0.296 & 9.9 \\
\hline 338 & 261.2 & 4.66 & 1.82 & 30.7 & 754 & 1.23 & 0.335 & 9.7 \\
\hline 343 & 264.3 & 5.13 & 1.97 & 29.9 & 771 & 1.32 & 0.414 & 11.9 \\
\hline 348 & 267.3 & 6.08 & 2.34 & 28.5 & 792 & 1.44 & 0.484 & 14.8 \\
\hline 353 & 270.4 & 6.65 & 2.58 & 27.9 & 855 & 1.47 & 0.457 & 12.2 \\
\hline 358 & 273.4 & 6.83 & 2.66 & 27.9 & 897 & 1.49 & 0.409 & 9.3 \\
\hline 363 & 276.5 & 7.19 & 2.81 & 27.3 & 902 & 1.51 & 0.423 & 10.2 \\
\hline 373 & 282.6 & 6.46 & 2.69 & 28.2 & 725 & 1.39 & 0.374 & 8.4 \\
\hline 378 & 285.6 & 5.78 & 2.29 & 29.6 & 582 & 1.09 & 0.316 & 8.0 \\
\hline 383 & 288.7 & 5.74 & 2.30 & 29.4 & 662 & 1.24 & 0.349 & 6.6 \\
\hline 388 & 291.7 & 5.87 & 2.51 & 29.1 & 691 & 1.24 & 0.317 & 6.6 \\
\hline 393 & 294.8 & 5.88 & 2.62 & 29.0 & 717 & 1.23 & 0.292 & 7.6 \\
\hline 398 & 297.8 & 5.78 & 2.59 & 29.2 & 763 & 1.25 & 0.280 & 6.8 \\
\hline 403 & 300.9 & 5.60 & 2.34 & 28.8 & 721 & 1.24 & 0.293 & 6.6 \\
\hline 408 & 303.9 & 5.68 & 2.41 & 28.4 & 675 & 1.25 & 0.339 & 8.3 \\
\hline 413 & 307 & 6.07 & 2.56 & 28.8 & 679 & 1.31 & 0.371 & 7.8 \\
\hline 418 & 310 & 6.42 & 2.39 & 28.6 & 889 & 1.36 & 0.336 & 6.2 \\
\hline 423 & 313.1 & 6.65 & 2.56 & 28.3 & 729 & 1.41 & 0.377 & 8.6 \\
\hline 428 & 316.1 & 6.08 & 2.26 & 29.3 & 775 & 1.31 & 0.314 & 6.2 \\
\hline 433 & 319.2 & 5.52 & 2.06 & 29.9 & 628 & 1.06 & 0.220 & 4.0 \\
\hline 438 & 322.2 & 5.69 & 2.39 & 29.3 & 683 & 1.23 & 0.250 & 3.8 \\
\hline 443 & 325.3 & 5.85 & 2.26 & 29.7 & 553 & 1.09 & 0.246 & 5.8 \\
\hline 448 & 328.3 & 6.76 & 2.06 & 29.1 & 507 & 1.16 & 0.319 & 6.3 \\
\hline 453 & 331.4 & 7.67 & 2.45 & 26.1 & 599 & 1.54 & 0.431 & 7.0 \\
\hline 458 & 334.4 & 6.35 & 2.07 & 28.0 & 607 & 1.30 & 0.358 & 6.4 \\
\hline 463 & 337.5 & 5.81 & 2.05 & 28.6 & 662 & 1.26 & & 3.8 \\
\hline 468 & 340.5 & 5.55 & 1.95 & 29.0 & 649 & 1.20 & 0.309 & 5.5 \\
\hline 473 & 343.6 & 5.30 & 2.06 & 29.9 & 687 & 1.16 & 0.331 & 6.6 \\
\hline 478 & 346.7 & 5.17 & 2.02 & 29.9 & 708 & 1.19 & 0.338 & 7.6 \\
\hline 483 & 349.7 & 5.48 & 2.21 & 28.7 & 645 & 1.21 & 0.388 & 10.4 \\
\hline 488 & 352.8 & 5.85 & 2.17 & 28.1 & 679 & 1.29 & 0.476 & 14.3 \\
\hline 498 & 358.9 & 5.31 & 1.93 & 30.4 & 696 & 1.07 & 0.328 & 12.9 \\
\hline 503 & 362 & 5.83 & 2.08 & 29.7 & 712 & 1.15 & 0.365 & 14.8 \\
\hline 508 & 365.1 & 6.53 & 2.45 & 28.6 & 729 & 1.23 & 0.391 & 14.7 \\
\hline 513 & 368.1 & 6.67 & 2.69 & 26.5 & 771 & 1.38 & 0.402 & 12.1 \\
\hline 518 & 371.2 & 6.47 & 2.85 & 27.2 & 763 & 1.37 & 0.377 & 10.7 \\
\hline 523 & 374.3 & 6.66 & 2.76 & 27.9 & 843 & 1.41 & 0.343 & 9.7 \\
\hline 528 & 377.3 & 6.37 & 2.60 & 28.1 & 834 & 1.37 & 0.328 & 10.9 \\
\hline 533 & 380.4 & 6.47 & 2.66 & 27.6 & 780 & 1.36 & 0.302 & 7.9 \\
\hline 538 & 383.5 & 6.92 & 2.83 & 27.7 & 826 & 1.41 & 0.310 & 11.4 \\
\hline 543 & 386.5 & 6.62 & 2.88 & 27.4 & 775 & 1.35 & 0.251 & 7.3 \\
\hline 548 & 389.6 & 8.81 & 3.89 & 24.2 & 780 & 1.65 & 0.279 & 7.6 \\
\hline 553 & 392.7 & 8.50 & 3.62 & 24.9 & 830 & 1.61 & 0.273 & 8.2 \\
\hline 558 & 395.7 & 7.93 & 3.53 & 24.7 & 708 & 1.49 & 0.251 & 8.5 \\
\hline 568 & 401.9 & 5.42 & 2.39 & 29.8 & 725 & 1.18 & 0.214 & 6.9 \\
\hline 573 & 404.9 & 5.18 & 2.10 & 30.0 & 540 & 0.96 & 0.196 & 5.7 \\
\hline
\end{tabular}




\begin{tabular}{|c|c|c|c|c|c|c|c|c|}
\hline 578 & 408 & 6.03 & 2.17 & 29.8 & 612 & 1.07 & 0.231 & 8.5 \\
\hline 603 & 423.8 & 5.56 & 2.16 & 28.6 & 637 & 1.25 & 0.425 & 13.3 \\
\hline 613 & 430.1 & 4.67 & 1.86 & 30.0 & 641 & 1.10 & 0.286 & 9.4 \\
\hline 623 & 436.5 & 5.74 & 2.32 & 28.7 & 662 & 1.29 & 0.397 & 16.8 \\
\hline 628 & 439.6 & 6.25 & 2.61 & 27.6 & 637 & 1.42 & 0.538 & 27.9 \\
\hline 633 & 442.8 & 6.42 & 2.55 & 28.0 & 700 & 1.48 & 0.505 & 30.3 \\
\hline 638 & 445.9 & 5.64 & 2.29 & 28.2 & 637 & 1.32 & 0.453 & 26.2 \\
\hline 648 & 452.3 & 5.32 & 2.07 & 29.4 & 557 & 1.05 & 0.335 & 14.1 \\
\hline 653 & 455.4 & 5.20 & 2.12 & 29.4 & 645 & 1.17 & 0.376 & 13.4 \\
\hline 658 & 458.6 & 5.41 & 2.24 & 29.0 & 675 & 1.18 & 0.364 & 12.5 \\
\hline 663 & 461.7 & 5.95 & 2.41 & 28.0 & 725 & 1.28 & 0.404 & 17.0 \\
\hline 668 & 464.9 & 6.77 & 2.90 & 27.1 & 788 & 1.37 & 0.345 & 14.0 \\
\hline 673 & 468.1 & 7.60 & 3.61 & 25.5 & 839 & 1.53 & 0.346 & 15.6 \\
\hline 683 & 474.4 & 8.55 & 3.49 & 24.7 & 826 & 1.70 & 0.388 & 18.5 \\
\hline 688 & 477.6 & 7.84 & 3.06 & 26.0 & 809 & 1.58 & 0.296 & 9.9 \\
\hline 693 & 482.5 & 7.48 & 2.88 & 26.6 & 750 & 1.50 & 0.284 & 11.4 \\
\hline 698 & 487.7 & 7.92 & 3.05 & 25.9 & 712 & 1.54 & 0.319 & 13.7 \\
\hline 703 & 493 & 8.40 & 3.28 & 25.3 & 721 & 1.62 & 0.361 & 14.7 \\
\hline 708 & 498.3 & 7.59 & 3.10 & 26.2 & 717 & 1.52 & 0.325 & 12.4 \\
\hline 713 & 503.6 & 7.31 & 2.82 & 26.7 & 754 & 1.49 & 0.297 & 10.7 \\
\hline 718 & 508.8 & 7.58 & 2.93 & 26.4 & 729 & 1.47 & 0.305 & 12.3 \\
\hline 723 & 514.1 & 8.06 & 3.11 & 25.9 & 733 & 1.55 & 0.343 & 12.9 \\
\hline 728 & 519.4 & 8.85 & 3.41 & 24.6 & 733 & 1.74 & 0.446 & 17.3 \\
\hline 733 & 524.7 & 7.64 & 2.96 & 26.1 & 687 & 1.53 & 0.425 & 16.1 \\
\hline 738 & 529.9 & 6.78 & 2.64 & 27.1 & 704 & 1.45 & 0.402 & 15.2 \\
\hline 743 & 535.2 & 6.45 & 2.59 & 27.6 & 704 & 1.39 & 0.386 & 14.6 \\
\hline 748 & 540.5 & 6.49 & 2.64 & 27.5 & 696 & 1.37 & 0.402 & 13.3 \\
\hline 753 & 545.8 & 6.92 & 2.91 & 26.7 & 746 & 1.47 & 0.434 & 14.0 \\
\hline 758 & 551 & 6.45 & 2.74 & 27.2 & 759 & 1.41 & 0.412 & 13.6 \\
\hline 763 & 556.3 & 6.26 & 2.57 & 27.7 & 813 & 1.37 & 0.356 & 10.5 \\
\hline 768 & 561.6 & 6.72 & 2.76 & 27.0 & 792 & 1.42 & 0.395 & 13.1 \\
\hline 773 & 566.9 & 7.45 & 3.12 & 26.0 & 767 & 1.51 & 0.417 & 16.0 \\
\hline 778 & 571.7 & 7.89 & 3.59 & 25.6 & 784 & 1.54 & 0.360 & 14.0 \\
\hline 783 & 575.6 & 7.38 & 3.37 & 26.3 & 830 & 1.47 & 0.305 & 11.9 \\
\hline 793 & 583.3 & 7.32 & 3.44 & 26.0 & 729 & 1.50 & 0.401 & 16.6 \\
\hline 798 & 587.2 & 7.10 & 3.09 & 26.3 & 708 & 1.45 & 0.449 & 14.0 \\
\hline 803 & 591.1 & 6.59 & 2.87 & 27.3 & 725 & 1.36 & 0.368 & 11.8 \\
\hline 808 & 595 & 6.69 & 3.00 & 27.0 & 763 & 1.43 & 0.362 & 15.5 \\
\hline 813 & 598.9 & 7.04 & 2.89 & 26.7 & 830 & 1.47 & 0.348 & 14.3 \\
\hline 818 & 602.8 & 7.26 & 2.89 & 26.7 & 759 & 1.48 & 0.318 & 11.9 \\
\hline 823 & 606.6 & 7.40 & 2.96 & 26.6 & 754 & 1.44 & 0.273 & 10.8 \\
\hline 828 & 610.5 & 7.42 & 2.93 & 26.6 & 792 & 1.49 & 0.276 & 10.4 \\
\hline 833 & 614.4 & 8.96 & 3.45 & 24.6 & 830 & 1.74 & 0.352 & 14.3 \\
\hline 838 & 618.3 & 10.44 & 4.03 & 22.5 & 733 & 1.96 & 0.540 & 18.8 \\
\hline 843 & 622.2 & 8.78 & 4.65 & 23.8 & 687 & 1.68 & 0.463 & 15.6 \\
\hline 848 & 626.1 & 6.90 & 4.57 & 26.0 & 679 & 1.43 & 0.396 & 11.2 \\
\hline 853 & 630 & 6.35 & 2.39 & 27.8 & 662 & 1.33 & 0.411 & 10.1 \\
\hline 858 & 634.2 & 6.49 & 2.51 & 27.6 & 670 & 1.37 & 0.450 & 11.4 \\
\hline 863 & 638.5 & 6.19 & 2.35 & 28.0 & 754 & 1.36 & 0.435 & 9.0 \\
\hline 868 & 642.7 & 6.41 & 2.50 & 27.7 & 704 & 1.34 & 0.437 & 11.4 \\
\hline 873 & 647 & 7.75 & 6.24 & 23.9 & 742 & 1.58 & 0.493 & 14.8 \\
\hline 878 & 651.2 & 8.49 & 3.06 & 24.9 & 717 & 1.67 & 0.569 & 12.9 \\
\hline 883 & 655.5 & 7.82 & 3.14 & 25.7 & 754 & 1.61 & 0.488 & 11.1 \\
\hline 888 & 659.7 & 7.08 & 2.70 & 26.9 & 704 & 1.39 & 0.436 & 9.2 \\
\hline 893 & 664 & 6.84 & 2.46 & 27.3 & 767 & 1.39 & 0.372 & 8.6 \\
\hline
\end{tabular}




\begin{tabular}{ccccccccc}
898 & 668.2 & 7.18 & 2.58 & 27.0 & 788 & 1.42 & 0.362 & 7.9 \\
903 & 672.5 & 9.08 & 3.34 & 24.6 & 805 & 1.70 & 0.451 & 10.5 \\
908 & 676.7 & 8.33 & 3.24 & 25.4 & 881 & 1.62 & 0.342 & 9.5 \\
913 & 681 & 9.11 & 3.53 & 24.5 & 864 & 1.63 & 0.321 & 10.5 \\
918 & 685.2 & 10.38 & 3.95 & 22.7 & 822 & 1.92 & 0.477 & 12.7 \\
923 & 689.5 & 8.22 & 3.53 & 25.3 & 822 & 1.62 & 0.338 & 11.0 \\
928 & 693.7 & 8.18 & 3.12 & 25.6 & 805 & 1.62 & 0.336 & 8.9 \\
933 & 698 & 7.42 & 3.02 & 26.4 & 847 & 1.52 & 0.319 & 10.7 \\
938 & 702.2 & 7.43 & 3.21 & 26.2 & 872 & 1.56 & 0.356 & 11.1 \\
943 & 706.5 & 7.57 & 3.19 & 25.6 & 1078 & 1.73 & 0.471 & 17.5 \\
948 & 710.7 & 6.66 & 2.77 & 26.6 & 1162 & 1.63 & 0.432 & 11.6 \\
953 & 715 & 7.19 & 3.06 & 26.0 & 1007 & 1.61 & 0.480 & 10.0 \\
958 & 719.2 & 7.00 & 3.33 & 26.2 & 923 & 1.53 & 0.447 & 8.6 \\
963 & 723.5 & 7.52 & 2.72 & 26.2 & 1091 & 1.70 & 0.500 & 9.9 \\
968 & 727.7 & 6.69 & 2.84 & 27.0 & 1082 & 1.58 & 0.393 & 8.4 \\
973 & 732 & 6.58 & 4.07 & 26.5 & 927 & 1.50 & 0.337 & 10.3 \\
978 & 736.3 & 7.47 & 3.42 & 25.8 & 893 & 1.69 & 0.403 & 9.7 \\
983 & 740.5 & 7.92 & 3.94 & 25.0 & 868 & 1.76 & 0.457 & 8.8 \\
\hline
\end{tabular}

Data gaps indicate measurement below detection limit 


\begin{tabular}{|c|c|c|c|c|}
\hline Mo (ppm) & Cd (ppm) & V (ppm) & $\mathrm{Cu}(\mathrm{ppm})$ & $\mathrm{Ba}(\mathrm{ppm})$ \\
\hline 8.6 & 11.8 & 178 & 245 & 1294 \\
\hline 7.0 & 18.4 & 140 & 173 & 1101 \\
\hline 8.5 & 16 & 169 & 237 & 1222 \\
\hline 10.5 & 10.4 & 134 & 165 & 1261 \\
\hline 15.0 & 17.6 & 184 & 211 & 1361 \\
\hline 19.2 & 22.5 & 209 & 244 & 1319 \\
\hline 15.8 & 18.4 & 164 & 200 & 1210 \\
\hline 10.8 & 30.6 & 150 & 174 & 1189 \\
\hline 11.7 & 22.8 & 146 & 178 & 1154 \\
\hline 11.2 & 17.9 & 157 & 182 & 1284 \\
\hline 14.2 & 16.4 & 182 & 204 & 1294 \\
\hline 19.2 & 21.1 & 191 & 239 & 1287 \\
\hline 21.7 & 20.9 & 203 & 237 & 1397 \\
\hline 21.7 & 30.5 & 195 & 236 & 1478 \\
\hline 19.7 & 14.4 & 195 & 225 & 1497 \\
\hline 22.8 & 18.7 & 208 & 237 & 1626 \\
\hline 24.1 & 19 & 207 & 251 & 1702 \\
\hline 29.7 & 15.4 & 230 & 283 & 1764 \\
\hline 30.8 & 16.2 & 200 & 269 & 1508 \\
\hline 28.1 & 20.3 & 198 & 264 & 1465 \\
\hline 39.0 & 37.7 & 246 & 323 & 1837 \\
\hline 40.5 & 21 & 220 & 294 & 1812 \\
\hline 33.9 & 24.1 & 205 & 264 & 1667 \\
\hline 32.5 & 20.3 & 183 & 252 & 1520 \\
\hline 23.7 & 21.6 & 188 & 248 & 1442 \\
\hline 19.6 & 6.0 & 184 & 250 & 1288 \\
\hline 17.4 & 22.1 & 206 & 243 & 1403 \\
\hline 21.7 & 9.2 & 218 & 303 & 1105 \\
\hline 14.1 & 18.4 & 209 & 247 & 1165 \\
\hline 7.1 & 13.2 & 172 & 196 & 1105 \\
\hline 18.5 & & 170 & 224 & 1283 \\
\hline 6.2 & 27 & 150 & 180 & 1165 \\
\hline 7.9 & 20.9 & 174 & 197 & 1231 \\
\hline 7.3 & 20.1 & 190 & 208 & 1283 \\
\hline 7.9 & 20.9 & 190 & 228 & 1231 \\
\hline 5.7 & 22.1 & 192 & 213 & 1274 \\
\hline 4.6 & 16.1 & 161 & 178 & 1334 \\
\hline 3.8 & 22.8 & 148 & 204 & 1357 \\
\hline 4.5 & 16.4 & 160 & 183 & 1385 \\
\hline 3.6 & 15.2 & 154 & 186 & 1355 \\
\hline 4.6 & 22.8 & 175 & 224 & 1498 \\
\hline 2.7 & 18.1 & 165 & 199 & 1398 \\
\hline 4.3 & 18.5 & 187 & 260 & 1474 \\
\hline 4.2 & 25.5 & 178 & 261 & 1541 \\
\hline 5.1 & 26.4 & 218 & 302 & 1773 \\
\hline 6.5 & 33.7 & 236 & 334 & 1720 \\
\hline 5.4 & 3.1 & 197 & 302 & 1375 \\
\hline 4.3 & 23.9 & 221 & 326 & 1460 \\
\hline 4.5 & 21.1 & 191 & 292 & 1287 \\
\hline 4.4 & 22.2 & 186 & 282 & 1388 \\
\hline 4.5 & 13.8 & 185 & 280 & 1427 \\
\hline 9.8 & 20.6 & 214 & 282 & 1520 \\
\hline 7.2 & 10.2 & 191 & 265 & 1343 \\
\hline
\end{tabular}




\begin{tabular}{|c|c|c|c|c|}
\hline 8.1 & 18.5 & 219 & 280 & 1376 \\
\hline 7.4 & 32.9 & 197 & 249 & 1373 \\
\hline 15.5 & 19.2 & 214 & 296 & 1486 \\
\hline 5.3 & 6.8 & 237 & 327 & 1331 \\
\hline 4.6 & 16.7 & 265 & 370 & 1285 \\
\hline \multirow[t]{7}{*}{4.9} & 16.9 & 274 & 380 & 1318 \\
\hline & 12.9 & 122 & 176 & 944 \\
\hline & 28.2 & 136 & 187 & 1106 \\
\hline & 21.0 & 134 & 157 & 1055 \\
\hline & 26.3 & 124 & 154 & 1123 \\
\hline & 18.9 & 143 & 189 & 1120 \\
\hline & 20.5 & 162 & 211 & 1235 \\
\hline 1.8 & 24.1 & 198 & 259 & 1307 \\
\hline 1.4 & 26.4 & 220 & 295 & 1458 \\
\hline 2.3 & 23.8 & 237 & 309 & 1534 \\
\hline 2.2 & 38.9 & 248 & 333 & 1617 \\
\hline 2.4 & 27.7 & 230 & 309 & 1456 \\
\hline 2.2 & 18.7 & 184 & 272 & 1182 \\
\hline 2.3 & 26.6 & 196 & 262 & 1230 \\
\hline 2.2 & 20.3 & 206 & 275 & 1318 \\
\hline 3.5 & 9.3 & 210 & 281 & 1377 \\
\hline 5.0 & 11.2 & 210 & 276 & 1383 \\
\hline 1.5 & 20.4 & 197 & 237 & 1351 \\
\hline 3.4 & 25.0 & 201 & 251 & 1332 \\
\hline 3.1 & 21.0 & 221 & 287 & 1296 \\
\hline 2.1 & 16.5 & 233 & 291 & 1421 \\
\hline 2.4 & 25.7 & 243 & 307 & 1381 \\
\hline 2.0 & 31.0 & 217 & 271 & 1400 \\
\hline 2.5 & 19.9 & 180 & 257 & 1197 \\
\hline 5.3 & 21.0 & 201 & 268 & 1268 \\
\hline 4.9 & 37.5 & 195 & 279 & 1160 \\
\hline \multirow[t]{2}{*}{1.9} & 21.6 & 217 & 314 & 922 \\
\hline & 25.4 & 287 & 329 & 1124 \\
\hline \multirow[t]{3}{*}{1.5} & 20.5 & 225 & 262 & 874 \\
\hline & 16.1 & 209 & 221 & 916 \\
\hline & 24.8 & 194 & 203 & 946 \\
\hline 1.6 & 21.4 & 177 & 211 & 1002 \\
\hline \multirow[t]{5}{*}{1.2} & 31.4 & 174 & 207 & 1039 \\
\hline & 9.0 & 180 & 203 & 998 \\
\hline & 18.2 & 189 & 217 & 1020 \\
\hline & 14.1 & 158 & 226 & 989 \\
\hline & 8.3 & 176 & 253 & 1119 \\
\hline 1.7 & 36.7 & 203 & 297 & 1250 \\
\hline 1.4 & 22.6 & 221 & 282 & 1374 \\
\hline 2.3 & 32.0 & 224 & 284 & 1401 \\
\hline 2.0 & 24.7 & 231 & 315 & 1426 \\
\hline 1.9 & 11.9 & 217 & 303 & 1373 \\
\hline 1.6 & 19.5 & 228 & 293 & 1453 \\
\hline 2.5 & 23.4 & 248 & 347 & 1462 \\
\hline 1.8 & 22.8 & 249 & 323 & 1533 \\
\hline 4.4 & 26.6 & 343 & 477 & 1816 \\
\hline 2.5 & 24.6 & 325 & 447 & 1792 \\
\hline 3.0 & 30.6 & 304 & 412 & 1622 \\
\hline \multirow[t]{2}{*}{2.5} & 10.3 & 191 & 263 & 1288 \\
\hline & 21.4 & 174 & 220 & 1092 \\
\hline
\end{tabular}




$\begin{array}{lcccc} & 23.7 & 197 & 271 & 1070 \\ & 10.6 & 180 & 198 & 1011 \\ & 21.1 & 145 & 167 & 906 \\ & 10.5 & 191 & 215 & 1018 \\ & 10.7 & 210 & 238 & 1120 \\ & 20.2 & 223 & 262 & 1142 \\ & 18.6 & 179 & 211 & 990 \\ & 22.1 & 166 & 212 & 942 \\ 1.1 & 20.5 & 164 & 202 & 957 \\ & 20.9 & 175 & 214 & 1070 \\ 1.8 & 19.5 & 199 & 244 & 1139 \\ 4.3 & 16.4 & 233 & 334 & 1233 \\ 2.2 & 21.4 & 284 & 367 & 1537 \\ & 20.3 & 327 & 408 & 1505 \\ 1.8 & 13.0 & 299 & 372 & 1274 \\ & 26.0 & 288 & 359 & 1179 \\ 2.7 & 16.6 & 302 & 384 & 1197 \\ 1.0 & 24.3 & 332 & 416 & 1309 \\ & 12.9 & 302 & 364 & 1203 \\ 1.4 & 24.5 & 287 & 331 & 1076 \\ & 17.3 & 297 & 341 & 1113 \\ 1.8 & 17.3 & 320 & 368 & 1190 \\ 1.5 & 21.4 & 352 & 420 & 1309 \\ 1.0 & 9.2 & 293 & 346 & 1169 \\ & 14.0 & 247 & 289 & 1087 \\ 1.1 & 19.3 & 236 & 266 & 1100 \\ & 27.5 & 230 & 269 & 1101 \\ & 25.3 & 259 & 287 & 1288 \\ & 24.7 & 238 & 270 & 1220 \\ 1.4 & 24.5 & 230 & 264 & 1226 \\ 1.1 & 17.7 & 243 & 296 & 1308 \\ 3.8 & 27.0 & 279 & 348 & 1448 \\ 3.6 & 23.0 & 319 & 403 & 1517 \\ 5.7 & 18.0 & 288 & 376 & 1516 \\ 4.0 & 15.8 & 286 & 370 & 1463 \\ 2.4 & 17.6 & 243 & 321 & 1290 \\ 4.1 & 23.4 & 246 & 308 & 1379 \\ 2.1 & 25.1 & 259 & 321 & 1329 \\ 1.6 & 24.8 & 274 & 336 & 1488 \\ 1.1 & 26.0 & 296 & 355 & 1491 \\ 1.4 & 36.5 & 285 & 354 & 1435 \\ 2.3 & 21.0 & 352 & 453 & 1465 \\ 3.9 & 28.5 & 420 & 538 & 1435 \\ 13.1 & 27.8 & 360 & 415 & 1461 \\ 16.8 & 22.6 & 269 & 304 & 1303 \\ & 12.5 & 223 & 210 & 947 \\ 1.0 & 29.2 & 231 & 220 & 985 \\ 1.5 & 28.7 & 214 & 205 & 1019 \\ & 17.8 & 221 & 210 & 1067 \\ & 29.4 & 327 & 363 & 1596 \\ & 22.4 & 313 & 310 & 1157 \\ & 19.8 & 293 & 298 & 1260 \\ & & 253 & 269 & 1181 \\ & & & 261 & 1215\end{array}$




\begin{tabular}{ccccc}
1.3 & 26.2 & 270 & 286 & 1340 \\
3.4 & 24.7 & 368 & 408 & 1481 \\
2.6 & 24.3 & 344 & 392 & 1575 \\
3.2 & 26.2 & 374 & 457 & 1640 \\
4.1 & 25.8 & 441 & 548 & 1569 \\
5.2 & 10.0 & 341 & 419 & 1367 \\
1.8 & 23.0 & 340 & 392 & 1285 \\
2.7 & 25.8 & 298 & 351 & 1266 \\
2.5 & 21.3 & 285 & 344 & 1241 \\
2.7 & 35.3 & 280 & 328 & 1202 \\
2.0 & 25.0 & 228 & 270 & 1075 \\
4.5 & 7.2 & 263 & 294 & 1073 \\
6.3 & 15.9 & 266 & 298 & 1081 \\
1.9 & 16.8 & 284 & 263 & 965 \\
2.7 & 22.8 & 255 & 240 & 1076 \\
13.8 & 23.3 & 275 & 296 & 1354 \\
5.7 & 24.0 & 311 & 301 & 1215 \\
9.7 & 21 & 341 & 353 & 1378 \\
\hline
\end{tabular}


$1000 \mathrm{~km}$
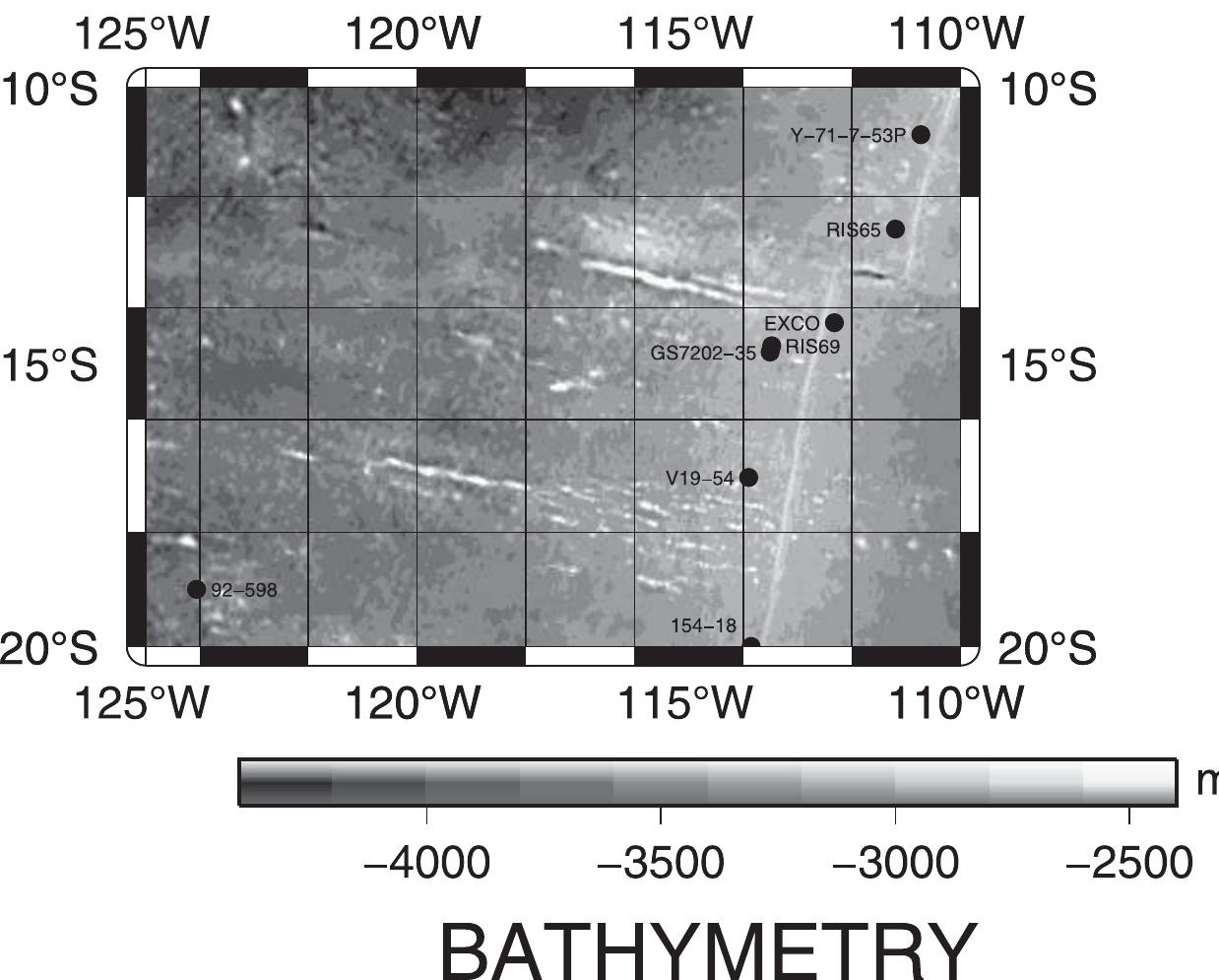


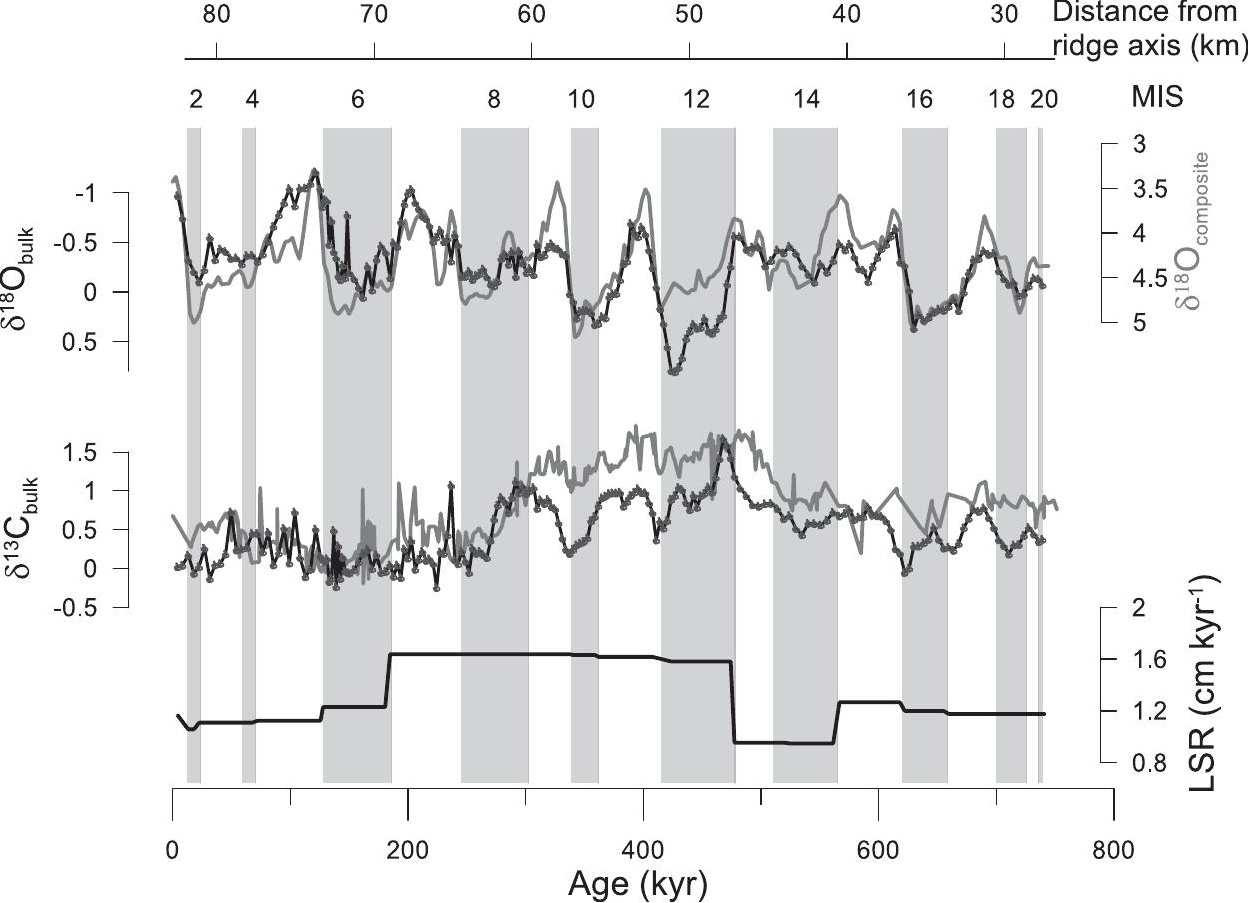




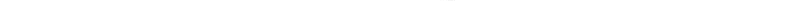


80

70

60

50

40

30 ridge axis $(\mathrm{km})$

(a) 24

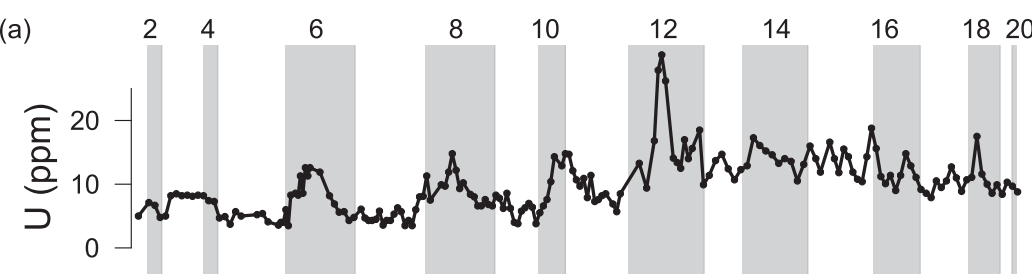

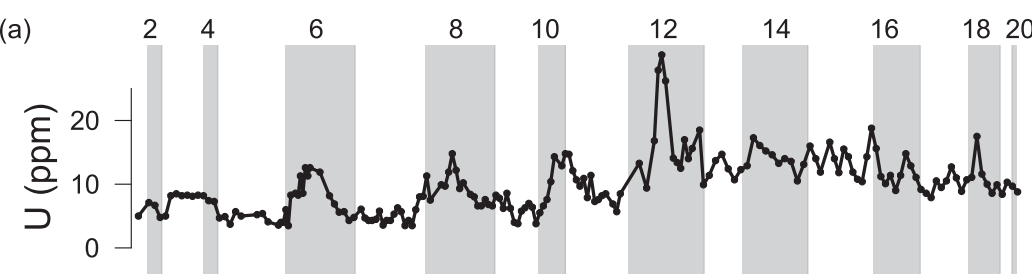

$12 \quad 14$

1

(c)

$\overbrace{}^{0.6}$

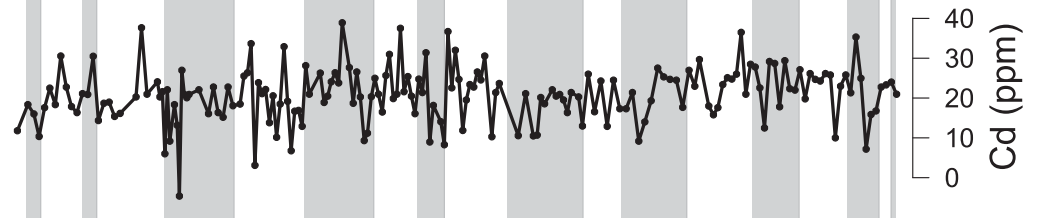

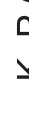

(e)

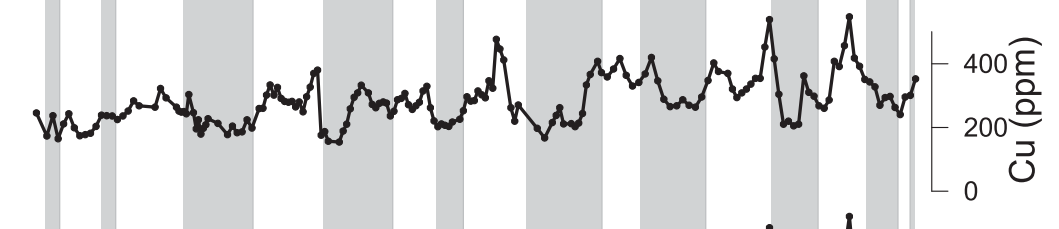

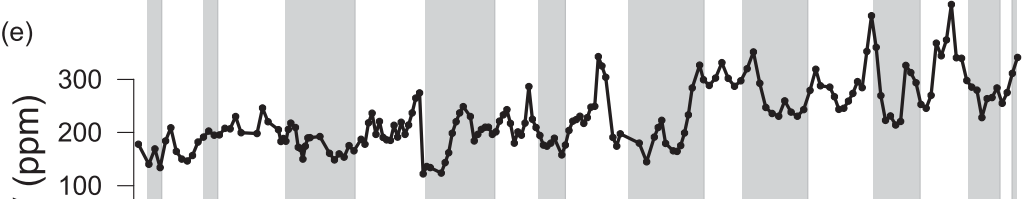

0

200

400

600

Age (kyr)

(d) 
80

70

50

40

30

Distance from

(a)

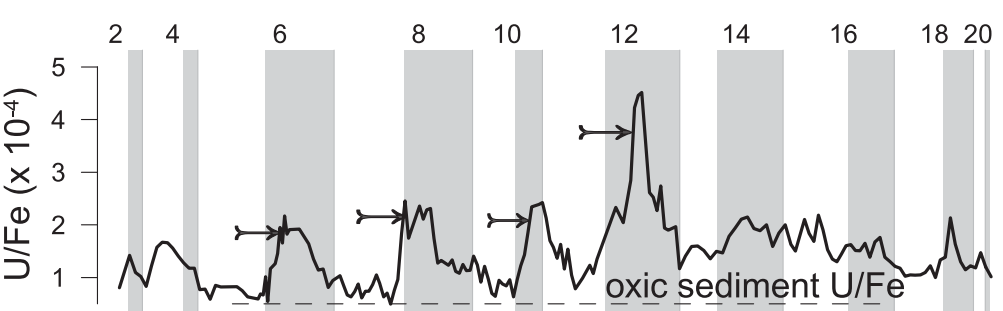

(c)

$-----\bar{\Lambda}--\bar{\Lambda}--\overline{\text { EPR }}$ plume $\overline{\mathrm{P}} / \mathrm{Fe}$

0.032 $N^{M}$ mivawWWAN

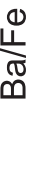
and ryprom

$W_{--1}$

EXCO plume $\mathrm{Ba} / \mathrm{Fe}$

0.008

(e)

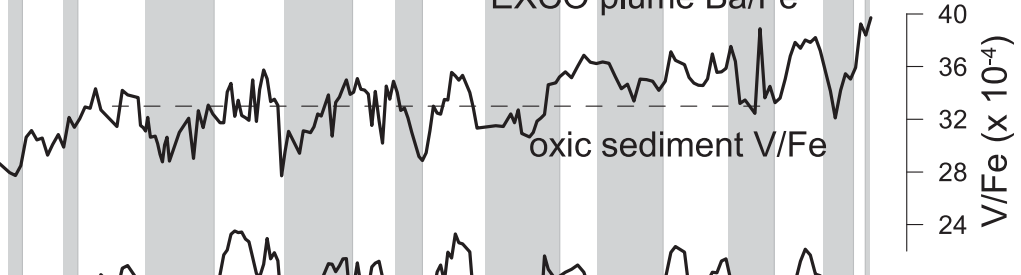

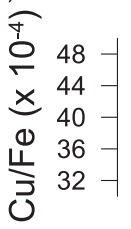

0

200

400

600

800

Age (kyr) 


\section{Pore} water profiles
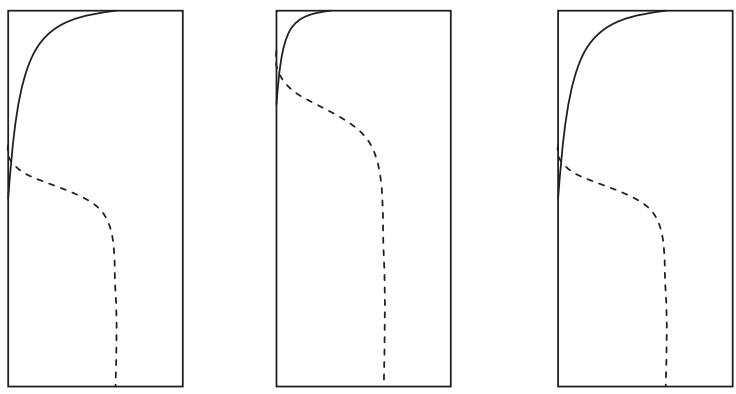

$\mathrm{O}_{2}$

$\mathrm{Mn}^{2+}$
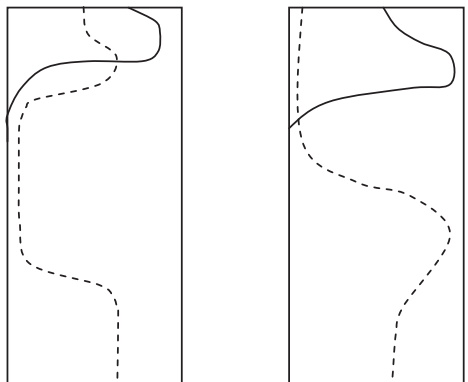

$\mathrm{Mo} / \mathrm{Mn}$
Solid phase profiles

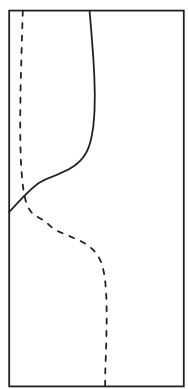

$\mathrm{U} / \mathrm{Fe}$ 
